\title{
The Morgan "Power" and the Forced Reconsideration of Constitutional Decisions
}

\author{
Stephen L. Carter $\dagger$
}

The Supreme Court's decisions on controversial issues invariably generate still greater controversy. Whatever romantic hopes the Framers might have had for the institution and the fate of its pronouncements, the reality is simple and somewhat sad: The Court's judgments on emotionally searing questions of constitutional law rarely settle them. Every celebrated decision seems to bring a celebrated condemnation of its immorality and a celebrated demand that it be overturned. Because amending the Constitution is practically impossible, altering federal court jurisdiction too controversial, and appointing new Justices an option rarely available, legislative circumvention and legislative override have become the strategies of choice for those who are disappointed with the Justices' conclusions. ${ }^{1}$ The most provocative and stimulating legislative proposals are often those possessing the most dubious claims to constitutionality. Into this category fall all those bills said to comprise exercises of the Morgan power.

The Morgan power derives its name and nearly all its rather

† Professor of Law, Yale University. An earlier version of this paper was presented at a meeting of the Yale Law School Faculty Workshop and my colleagues were, as usual, generous in their criticism. I have benefited in particular from more detailed comments by, criticisms from, and discussions with Enola Aird, Akhil Amar, Boris Bittker, Lea Brilmayer, Drew Days, Lucinda Finley, Geoffrey Hazard, and Burke Marshall, as well as from the research assistance of Lynda-Susan Blake.

' Such efforts as jurisdiction-stripping and court-packing, even if adopted and even if sustained, are crude methods of challenging the Court because they do not necessarily raise direct challenges to the decisions that motivate them. In particular, removing the jurisdiction of the Supreme Court over specified classes of cases overturns no precedent. See Sager, The Supreme Court, 1980 Term-Foreword: Constitutional Limitations on Congress' Authority to Regulate the Jurisdiction of the Federal Courts, 95 HaRv. L. REv. 17, 40-42 (1981). Court-packing efforts, as Franklin Roosevelt learned, may well call into question the legitimacy of the government seeking to impose them, and will certainly provide ammunition for one's political opponents. See William Leuchtenburg, FrankLin Roosevelt and THE New Deal 232-39 (1963). Even those who, like President Reagan, are determined to alter the Court's decisions prefer to await retirements rather than trying to increase the number of Justices. Whatever tools Congress uses to express its disapproval of the Court's doctrines, the stakes are high. See Charles Black, The People and the Court 56-86 (1960) (noting how judicial review promotes the legitimacy of the entire government). 
ethereal substance from the Supreme Court's 1966 decision in Katzenbach $v$. Morgan. ${ }^{2}$ In that case, the Warren Court sustained the constitutionality of section 4(e) of the Voting Rights Act of 1965, a provision essentially barring the enforcement of New York's English literacy requirement against otherwise qualified voters who are educated in Puerto Rico. ${ }^{3}$ The result might have generated relatively little controversy but for the Court's conclusion seven years earlier in Lassiter $v$. Northampton County Board of Elections ${ }^{4}$ that literacy tests did not violate the fourteenth and fifteenth amendments absent some showing of discriminatory application. Was the Congress tacitly asserting the forbidden power to revise the Court's constitutional judgments by ordinary legislation? ${ }^{5}$ Not at all, the Court concluded. The congressional action, Justice Brennan explained for the Morgan majority, was valid as an exercise of its power under section 5 of the fourteenth amendment to enforce the amendment's provisions by "appropriate legislation." The majority cautioned, however, that the Congress has the power only to broaden the scope of fourteenth amendment rights, not to narrow it. $^{2}$

2384 U.S. 641 (1966).

3 Voting Rights Act of 1965, § 4(e), 42 U.S.C. § 1973b(e) (1982).

360 U.S. 45 (1959).

- One less obvious way in which section $4(e)$ altered the substantive rule of decision established in Lassiter was by focusing on discriminatory effect rather than intent; there was no claim that the New York law that the Congress sought to override was enacted for any discriminatory purpose. Morgan, 384 U.S. at 653-56. The Court has since made clear that the Congress possesses the authority to make such a change. See City of Rome v. United States, 446 U.S. 156 (1980).

${ }^{8}$ Morgan, 384 U.S. at 653. Section 5 reads in its entirety: "The Congress shall have power to enforce, by appropriate legislation, the provisions of this article." U.S. ConsT. amend. XIV, § 5 .

2 Morgan, 384 U.S. at 651 n.10. Justice Brennan's footnote 10 does not expressly state that the Congress has the power to "broaden" fourteenth amendment rights. However, that is the implication of his statement that Congress may "enforce" but not "restrict, abrogate, or dilute" those rights. Justice Brennan's approach is further discussed infra at notes 24-30 and accompanying text.

A less controversial basis for the decision in Morgan would have been to rely on the plenary congressional authority over the territories of the United States, including Puerto Rico. I am told by my colleague Burke Marshall, who headed the Civil Rights Division of the Justice Department in the early sixties, that some Department lawyers urged that the Voting Rights Act be grounded in this plenary authority rather than in section 5 of the fourteenth amendment. On this theory, the legislation would represent congressional protection of congressional prerogative: If the Congress has decreed that American citizens attending the Puerto Rican public schools shall be instructed in Spanish, then no state may through its voting rules interfere with this determination. Cf. Chardes Black, Structure AND RELATIONSHIP IN CONSTITUTIONAL LAW 8-13 (1969) (analogous argument concerning state laws disenfranchising those in the armed forces). The Court in Morgan noted this ground but did not consider it. 384 U.S. at 646 n.5. 
Morgan had its challengers from the day it was decided, but its interpretation of section 5 is so consonant with the dominant liberal ideal of a dynamic society evolving toward justice ${ }^{8}$ that, until recently, its critics were not taken seriously. ${ }^{\text {' }}$ In fact, Morgan itself was neglected for years. Since 1965, only a handful of opinions have discussed the Morgan power. ${ }^{10}$ Outside the voting rights field in which the doctrine originated, ${ }^{11}$ a majority of the Court has never again relied on Morgan in reaching a decision-perhaps because the Congress has not often relied upon this power in legislating. So the Morgan power might have provided no more than a curious footnote to constitutional theory, but for its resurrection in the heated academic and political debate engendered by the Supreme Court's 1973 decision in Roe v. Wade. ${ }^{12}$

Ever since the Court's ruling that the constitutional right to privacy is at least in some circumstances broad enough to encompass a woman's choice whether to end her pregnancy, a substantial minority of the American public has sought to overturn or limit the breadth of the decision. In 1981, a young lawyer named Stephen Galebach wrote an article in the Human Life Review proposing that the Congress use its Morgan power to enact legislation that would in practical effect reverse Roe $v$. Wade. ${ }^{13}$ Could the

see Cox, The Supreme Court, 1965 Term-Foreword: Constitutional Adjudication and the Promotion of Human Rights, 80 HARv. L. REv. 91, 107 (1966) [hereinafter cited as Human Rights] ("The Morgan case . . . clears the way for a vast expansion of congressional legislation promoting human rights."). I mean by this and other textual references to "liberalism" the ideal of classical liberalism, see infra text accompanying notes 89-94, not necessarily any aspect of the platform of the contemporary "liberal" political faction. For a more detailed account of my vision of classical liberalism and its relation to judicial decisionmaking, see Carter, Constitutional Adjudication and the Indeterminate Text: A Preliminary Defense of an Imperfect Muddle, 94 YALE L.J. 821, 825-27, 865-70 (1985) [hereinafter cited as Indeterminate Text].

- The reason may have been that would-be critics believed that the voting rights controversies from which the Morgan power arose were "largely obsolete," and that the Congress was unlikely to make further important use of the power. See Cohen, Congressional Power to Interpret Due Process and Equal Protection, 27 Stan. L. Rev. 603, 619-20 (1975).

${ }^{10}$ For cases outside the voting rights area, see, for example, Mississippi University for Women v. Hogan, 458 U.S. 718, 731-33 (1982); Fullilove v. Klutznick, 448 U.S. 448, 476-77 (1980) (plurality opinion); Regents of the University of California v. Bakke, 438 U.S. 265, 373 (1978) (opinion of Justices Brennan, White, Marshall, and Blackmun, concurring in part and dissenting in part).

${ }^{11}$ For voting rights cases, see, for example, City of Rome v. United States, 446 U.S. 156, 176 (1980); Oregon v. Mitchell, 400 U.S. 112, 132-33 (1970) (Black, J.); id. at 141 (Douglas, J.); id. at 248 (Brennan, White, and Marshall, JJ.).

12410 U.S. 113 (1973).

13 Galebach, A Human Life Statute, 7 The Human Lrfe Review 3 (1981), reprinted in The Human Life Bill: Hearings on S. 158 Before the Subcomm. on Separation of Powers of the Senate Judiciary Comm., 97th Cong., 1st Sess. 205 (1982) [hereinafter cited as 
Congress not, he asked, just as it had extended the voting rights of some Americans through the Voting Rights Act, also extend the rights of the fetus-rights that the Court acknowledged in Roe as those that the state can sometimes protect? ${ }^{14}$

In the academic community, on Capitol Hill, and among rights activists on both sides of the abortion debate, the Galebach proposal ignited a firestorm of controversy. ${ }^{15}$ A "Human Life Bill" on the Galebach model was introduced in the Senate in $1981 .{ }^{16}$ Many

Hearings].

${ }^{14}$ Id. at 210-22; see Roe, 410 U.S. at 162-65 (concluding that the state possesses a compelling interest in protecting the potential life of a viable fetus).

${ }^{16}$ The bill proposed by Mr. Galebach read as follows:

The Congress finds that present day scientific evidence indicates a significant likelihood that actual human life exists from conception.

Upon the basis of this finding, and in the exercise of the powers of the Congress, including its power under Section 5 of the Fourteenth Amendment to the Constitution of the United States, the Congress hereby declares that for the purpose of enforcing the obligation of the States under the Fourteenth Amendment not to deprive persons of life without due process of law, human life shall be deemed to exist from conception, without regard to race, age, health, defect, or condition of dependency; and for this purpose "person" shall include all human life as defined herein.

Galebach, supra note 13, at 3. In this form, the proposal lacked explicit enforcement measures; it was simply a declaration of the Congress's findings and their constitutional significance. Nonetheless, if enacted in this form, the proposal might have enabled the states to forbid all abortions. Further, Mr. Galebach asserted in his article that the Congress has the power under section 5 to do more than "act by declaration without further enforcement." Id. at 25 .

Although Mr. Galebach's article embraced the Morgan power, his testimony before the Congress was somewhat more equivocal. There he argued that the Congress could constitutionally enact declaratory legislation because it would be "merely exercising its prerogative to inform the Court of its views." Hearings, supra note 13, at 200 (testimony of Stephen Galebach).

As far as I am aware, proponents of the Human Life Bill make no claim that a state legislature would possess similar powers of definition. See Doe v. Israel, 358 F. Supp. 1193 (D.R.I.), aff'd, 482 F.2d 156 (Ist Cir. 1973), cert. denied, 416 U.S. 993 (1974) (rejecting effort by a state legislature to ban abortion through defining the point at which life begins).

${ }^{16} \mathrm{~S}$. 158, 97th Cong., 1st Sess., 127 Cong. Rec. 496 (1981). The Bill was approved in 1981 by a 3-2 vote of the subcommittee on Separation of Powers of the Senate Judiciary Committee, but it subsequently died in the 97th Congress. Similar legislation was introduced in the 98th Congress. See S. 26, 98th Cong., 1st Sess., 129 Cong. REc. S90 (daily ed. Jan. 26, 1983). In the 99th Congress, pro-life forces chose a new tack, trying to amend existing civil rights legislation to protect "unborn" or "preborn" children. See S. 46, 99th Cong., 1st Sess., 130 Cong. Rec. S19 (daily ed. Jan. 3, 1985); H.R. 555, 99th Cong., 1st Sess., 130 Cong. REc. H128 (daily ed. Jan. 22, 1985). Many of the constitutional considerations discussed in this article are common to all the proposals.

The original Human Life Bill went further than the Galebach proposal by including section 2 which purports to strip the lower federal courts of jurisdiction to grant equitable relief in some abortion cases. Article III probably permits legislation of this kind. See Amar, A Neo-Federalist View of Article III: Separating the Two Tiers of Federal Jurisdiction, 65 B.U.L. REv. 205, 258 (1985); cf. Galebach, The Constitutionality of Withdrawal of Lower Federal Court Jurisdiction in the Human Life Bill, in Hearings, supra note 13, at 235, 241 
pro-life politicians and activists endorsed it at once, but scholarly comment (not all of it from pro-choice scholars) has been almost uniformly critical. ${ }^{17}$ The critics fall into two camps: those who believe the Bill is unconstitutional because it falls outside the proper scope of the Morgan power, and those who believe the Bill is unconstitutional because Katzenbach $v$. Morgan was wrongly decided.

Scholars who reject the Morgan power have the easier task. But those scholars who would preserve the Morgan power and yet reject the Galebach proposal face the difficulty of making a principled distinction between the Voting Rights Act and the Human Life Bill. At first glance, their job seems easy. The Human Life Bill, after all, appears to restrict a right that the Court has deemed fundamental-an action that is plainly beyond the power of the Congress. A close assessment of this and other arguments against the Bill, however, suggests that the search for a definition of the Morgan power that excludes the Human Life Bill is more hazardous than it appears, proceeding down uncertain paths thick with question-begging snarls, deadly weeds of indeterminacy, and other traps for the unwary.

My purpose in undertaking this assessment is not to express a view on the constitutionality of the Human Life Bill itself, and cer-

(asserting constitutionality of section 2). Because of the Supreme Court's often bizarre insistence on analyzing legislative motivation, however, section 2 might be vulnerable to constitutional challenge on the ground that it arises from hostility to a fundamental right. See Tribe, Jurisdictional Gerrymandering: Zoning Disfavored Rights Out of the Federal Courts, 16 Harv. C.R.-C.L. L. Rev. 129 (1981).

In this article I am not concerned with section 2. Rather I address what advocates of the Bill admit to be the full implications of section 1 under the Morgan power. When generally discussing "the Human Life Bill," I mean to include all varieties of legislation other than constitutional amendment that would challenge Roe through a declaration on the "personhood" of the fetus.

${ }^{17}$ For particularly scathing scholarly critiques, see Cox, Congress $v$. The Supreme Court, 33 Mercer L. REv. 707 (1982) [hereinafter cited as The Supreme Court]; Emerson, The Power of Congress to Change Constitutional Decisions of the Supreme Court: The Human Life Bill, 77 Nw. U.L. Rev. 129 (1982); Estreicher, Congressional Power and Constitutional Rights: Reflections on Proposed "Human Life" Legislation, 68 VA. L. REv. 333 (1982). In addition, the overwhelming majority of legal scholars who testified against the bill were critical of the Galebach analysis. See, e.g., Hearings, supra note 13, at 242-56 (testimony and prepared statement of Laurence Tribe); id., Appendix Volume, at 793-808 [hereinafter cited as Appendix to Hearings] (memorandum of R. Lea Brilmayer); id. at 824-25 (letter of Norman Dorsen). Prominent opponents of the Galebach proposal have included several scholars who believe that Roe $v$. Wade was wrongly decided. See, e.g., Hearings, supra note 13, at 308-16 (testimony and prepared statement of Robert Bork); id. at 195-97 (letter of Charles Alan Wright). A few constitutional scholars testified that the legislation was probably constitutional. See, e.g., id. at 256-75 (testimony and prepared statement of John T. Noonan); id. at 317-27 (testimony and prepared statement of Robert Nagel). 
tainly not to support or to oppose its passage. Rather, I hope to use a critique of the debate over the Human Life Bill to criticize a form of argument that has become shockingly common in these days since the constitutional deluge: adopting the deceptively neutral-sounding phrases of constitutional law as a way of avoiding the need to discuss tougher questions of morality and justice. Constitutional theory, I will contend, must do more than serve as an instrument for achieving political goals. All too often, the justifications for Morgan offered in the debate over the proposed Human Life Bill are purely instrumental-they are chosen in order to reach the desired result and are only then cast as positive structural constitutional law. As a consequence, they are simply not good theory.

My claim is not that Katzenbach $v$. Morgan was wrongly decided or that the Human Life Bill would necessarily pass constitutional muster. A convincing analysis of these propositions, however, ought to follow an approach markedly different from the mainstream arguments in favor of the Morgan power. A richer and more coherent approach, one I sketch lightly at the end of this paper, would be to abandon the effort to demonstrate the flat unconstitutionality of the Human Life Bill, and to focus instead on locating congressional action under the Morgan power within a continuing dialogue among the Justices and their various constituencies. The Morgan power, I argue, is best understood as a tool that permits the Congress to use its power to enact ordinary legislation to engage the Court in a dialogue about our fundamental rights, thereby "forcing" the Justices to take a fresh look at their own judgments. Congressional exercises of the Morgan power thus play an important role in the moral evolution of society-and are most effectively opposed on moral grounds.

\section{Locating the Morgan Power}

The Morgan principle is deceptively pleasant. One of the popular justifications for what is sometimes called noninterpretive or nontextual judicial review is that when Congress falters in the march toward a just society, then the courts can (and ought to) step in and fill the breach. ${ }^{18}$ Katzenbach $v$. Morgan stands for what must have seemed at the time of the decision to be the miss-

${ }^{18}$ An impassioned, although much-criticized, statement of this view is MrCHaEr PERRy, The Constitution, the Courts, and Human Rights (1982). Professor Perry's views have evolved since the publication of his book. See Perry, The Authority of Text, Tradition, and Reason: A Theory of Constitutional "Interpretation," 58 S. CaL. L. REv. 551 (1985). 
ing link to the promise of a better future through law: When the courts falter in the march toward a just society, the Congress can step in and fill the breach. If both propositions are simultaneously true, then the American constitutional process promotes social progress in a wonderfully symbiotic way: The Congress moves forward, then falters, the courts take the lead for a time, then they falter, the Congress takes over until the courts are rested, then the courts again resume leading, and so on. The cycle seems one of unending (if slightly monotonous) forward motion, one in which the judgment on what constitutes progress can be made equally by either actor, and one in which neither actor can slow the march.

But the manner in which I have stated this vision of progress holds a clue to the analytical difficulties the Morgan decision has spawned: Like so much received constitutional doctrine, it lacks substantive standards. How does an observer judge when the movement is in the proper direction? After all, although the Supreme Court has led the way in banishing organized prayer from the public schools, ${ }^{19}$ most Americans think the Justices are wrong. ${ }^{20}$ And while the Congress has consistently worked to limit pregnant women's access to abortions, ${ }^{21}$ most Americans think the Congress is wrong. ${ }^{22}$ Who is moving toward a just society? Who is

1s See Engel v. Vitale, 370 U.S. 421 (1962) (banning spoken state-composed prayer); Abington School Dist. v. Schempp, 374 U.S. 203 (1963) (banning spoken prayer taken from religious works); Stone v. Graham, 449 U.S. 39 (1980) (banning words of prayer hanging on wall); Wallace v. Jaffree, $105 \mathrm{~S}$. Ct. 2479 (1985) (banning moment of silence "for meditation or voluntary prayer").

${ }^{20}$ As recently as 1983 , some $81 \%$ of those respondents who said they were aware of the proposed constitutional amendment to permit voluntary organized prayer in the public school classroom stated that they were in favor of it. The Gallup Report, No. 217, at 17-19 (Oct. 1983). Since $82 \%$ of all respondents knew of the amendment, very nearly two-thirds of the American public probably favors it.

${ }^{11}$ See Hyde Amendment, Pub. L. 96-123, § 109, 93 Stat. 926 (1980), sustained in Harris v. McRae, 448 U.S. 297 (1980).

12 The American public has long been ambivalent about abortion, condemning it in some situations but consistently and overwhelmingly opposing an outright ban on the practice in all circumstances. Thus a recent CBS News/New York Times poll found that while $55 \%$ of respondents considered abortion the same as the murder of a child, two-thirds of those polled believed that abortion was sometimes the best solution to a difficult problem. N.Y. Times, Feb. 23, 1986, at 22E, col. 4. A number of careful surveys have found substantial public support for the right to choose abortion in cases involving life or health, but far smaller support, sometimes less than a majority, when the woman seeks abortion because she cannot afford any more children or because she simply does not want a child. See, e.g., Kristin Luker, ABortion aNd the Politics of Motherhood 224-26 (1984); Jackson \& Vinovskis, Public Opinion, Elections, and the "Single-Issue" Issue, in The ABortion Dispute AND THE AmERICAN System 64, 65 (G. Steiner ed. 1983) (analyzing survey results). As Dr. Luker points out, support for abortion, including abortion on demand, increased throughout the 1970 s and into the early 1980s. See K. LuKER, supra, at 225 . Although in recent years 
faltering? The envisaged symbiotic relationship cannot by itself provide answers to these questions.

No other vision, however, can fully explain the reasoning of the Morgan majority. In fact, in the absence of a substantive theory of progress, Morgan is a difficult decision to justify. Section 4(e) of the Voting Rights Act, the provision sustained in Morgan, can fairly be described as a congressional effort to overturn a constitutional decision of the Supreme Court. Unfortunately for the advocates of progress by any means, the evolution of our legal system has carried us past the point (if one ever existed) at which the Congress might reasonably have claimed a general authority to revise the Court's decisions through ordinary legislation. Unless a coherent limiting principle is established, the Morgan decision thus appears quite destructive of constitutional tradition.

One might, of course, try to avoid the need for principle by taking the easy way out. Perhaps the Congress, when acting under the Morgan power, is not disagreeing with the Court on what the Constitution requires. Plainly, to say that the Congress may grant the right is not to say that the right itself will thenceforth be of constitutional dimension. An exercise of the Morgan power may be no different from the enactment of any statute meant to grant a petitioner something she did not previously possess. Section 5 can simply be seen as a grant of power to the Congress to enact civil rights legislation, just as the Congress has power under the commerce clause to enact social welfare, telecommunication, or urban development legislation. Just as in these other areas, legislation under section 5 should be presumed valid unless a complainant can show that it impairs some constitutional right. In fact, to say that the congressionally granted right is valid only if no constitutional right is restricted-a popular formulation of the Morgan power-is in effect to deny the constitutional dimension of congressional action pursuant to the power. After all, when two constitutional

that support has fallen off somewhat, $40 \%$ of respondents in the CBS News/New York Times poll just mentioned would keep abortion a private decision for every woman. See N.Y. Times, Feb. 23, 1986, at 22E, col. 4.

Men are far more likely than women to support broad abortion rights. See id. Catharine MacKinnon has explained this phenomenon by suggesting that a male-dominated society permits abortion primarily to facilitate the heterosexual availability of women. See MacKinnon, The Male Ideology of Privacy: A Feminist Perspective on the Right to Abortion, in RADICAL AMERICA 23 (1983). Another possibility is that men, because their dialogue emphasizes competing and (for them) relatively abstract claims of right, may find the problem easier to resolve than will many women, who might instead find in the abortion dilemma a more personal conflict of responsibilities. See Carol Gilligan, IN a Different Voice 70-105 (1982). 
rights are in conflict, the typical judicial response is to balance them, not to declare one wholly invalid. ${ }^{23}$

Yet matters cannot possibly be so simple. All the shouting after Katzenbach v. Morgan was plainly about something. The "something" must be that the language of section 5 gives the Congress a power to "enforce" the guarantees of the fourteenth amendment, whereas the Voting Rights Act arguably required the exercise of a plenary power to protect against state interference rights not embodied in those guarantees. Because the Congress possesses no general regulatory authority over nonfederal elections, however, section 5 is the only possible source of that plenary authority. Thus the separation of powers inquiry: How can the Congress claim to be enforcing the fourteenth amendment by creating a right in potential voters not to be subjected to what the amendment does not by its own force prohibit?

Justice Brennan, recognizing this difficulty, sought in his opinion for the Court in Morgan to provide a limiting principle. He articulated what appears to be a three-part test. To be a valid exercise of the Congress's power under section 5 of the fourteenth amendment "to exercise its discretion in determining whether and what legislation is needed to secure the guarantees of the fourteenth amendment," actment to enforce the Equal Protection Clause," (2) be " "plainly adapted to that end," " and (3) not be "prohibited by" but instead be "consistent with 'the letter and spirit of the Constitution." "2s

That test by its own terms would probably outlaw very little. It designedly mirrors the test for determining whether legislation comports with the necessary and proper clause ${ }^{26}$ - a test containing no bite whatsoever. ${ }^{27}$ Plainly aware of the danger in granting the

23 For this reason, Robert Bork, in his testimony opposing the Human Life Bill, presented the fascinating argument that even if enacted and even if constitutional, the Bill would not necessarily alter the Roe result. Instead, he suggested, the Court would be called upon to balance the fetus's right to life against the pregnant woman's right to privacy, and the result of the balancing might be a "constitutional law of abortions" virtually identical to the rules announced in Roe. See Hearings, supra note 13, at 309 . Stephen Galebach insisted in his testimony that the Bill does not deny the existence of the woman's privacy right, and that the balance would still be struck by the Court. Id. at 200 (testimony of Stephen Galebach).

34384 U.S. at 651.

25 Id. (quoting McCulloch v. Maryland, 17 U.S. (4 Wheat.) 316, 421 (1819)).

26 "The Congress shall have Power. . . To make all Laws which shall be necessary and proper for carrying into Execution the foregoing Powers, and all other Powers vested by this Constitution in the Government of the United States, or in any Department or Officer thereof." U.S. Const. art. I, § 8, cl. 18.

${ }^{27}$ At least two writers have tried to use.the necessary and proper clause to explain and 
Congress a plenary authority under section 5 , but nevertheless determined to walk the tightrope of permitting the Court to sustain this provision of the Voting Rights Act while reserving the right to invalidate other legislation under section 5 , Justice Brennan qualified the test in his controversial footnote 10:

We emphasize that Congress' power under $\S 5$ is limited to adopting measures to enforce the guarantees of the Amendment; $\S 5$ grants Congress no power to restrict, abrogate, or dilute these guarantees. Thus, for example, an enactment authorizing the States to establish racially segregated systems of education would not be . . . a measure "to enforce" the Equal Protection Clause since that clause of its own force prohibits such state laws. ${ }^{28}$

These dicta constitute the real Morgan "test," because this footnote is the only part of the opinion dealing with what the Congress cannot do. The congressional initiative at issue must "enforce" rather than "restrict, abrogate, or dilute" the guarantees of the fourteenth amendment.

Even armed with this footnote, however, it is no easy task to try to state a single, coherent rule for distinguishing between proper and improper exercises of the Morgan power. Legal scholars have tried for twenty years to explain how an interpreter can tell whether the Congress is enforcing a constitutional guarantee or restricting it, ${ }^{29}$ and how the congressional power can logically be lim-

limit the Morgan power. See Buchanan, Katzenbach v. Morgan and Congressional Enforcement Power Under the Fourteenth Amendment: A Study in Conceptual Confusion, 17 Hous. L. Rev. 69, 116-17 (1979); Note, Toward Limits on Congressional Enforcement Power Under the Civil War Amendments, 34 STAN. L. REv. 453 (1982). Both writers justify Section 4(e) on the ground that it meets the "test" articulated in McCulloch v. Maryland, 17 U.S. (4 Wheat.) 316,421 (1819), to judge whether legislation is authorized under the necessary and proper clause. The Reconstruction Congress that drafted the fourteenth amendment, however, considered and rejected the insertion of an analogue to that clause rather than the current language of section 5. See Morgan, 384 U.S. at 659 n.9; Bickel, The Original Understanding and the Segregation Decision, 69 HARv. L. REv. 1, 29-40 (1955).

Nor does the language of $\mathrm{McCulloch}$ itself support the argument. Chief Justice Marshall's opinion for the Court set out no "test" to determine whether legislation was authorized by the Clause. Instead, responding to one not very clever argument by counsel for the state of Maryland, he explained why the clause did not forbid the congressional action. $\mathrm{He}$ did not claim that the clause was itself the font of any congressional power. See C. BLAck, supra note 7, at 13-14. As to my own earlier views on broad analogies that might be drawn to the necessary and proper clause, see Carter, The Political Aspects of Judicial Power: Some Notes on the Presidential Immunity Decision, 131 U. PA. L. REv. 1341, 1377-84 (1983) [hereinafter cited as Judicial Power], I confess error.

28384 U.S. at $651-52$ n.10.

${ }^{29}$ See, e.g., Cox, The Role of Congress in Constitutional Determinations, 40 U. Cin. L. 
ited to revision in only one direction. ${ }^{30}$ As will be seen, the effort has not yet succeeded. More difficult still-and here is the conundrum presented by the instant debate-is the crafting of a relatively neutral rule that recognizes section $4(\mathrm{e})$ of the Voting Rights Act as a constitutionally legitimate exercise of this power, while plainly excluding the Human Life Bill from its ambit. Yet a neutral rule is what the Bill's academic critics must find, for they seek to convince the Congress that the constitutionality of the proposal turns not on one's views about whether abortion should be a matter for individual choice, but rather on the dire implications for the separation of powers that would follow upon a legislative effort at restricting the rights conferred by (any!) Supreme Court decision.

The mainstream case against the Human Life Bill is quite straightforward. As one critic has put it, the Bill, if adopted and if constitutional, would "alter radically the basic separation of powers between the legislative and judicial branches of the national government as well as the boundaries between federal and state political activity." Af1 After all, the Supreme Court has ruled in quite clear and unequivocal terms that the right to privacy in some circumstances includes the decision whether to end a pregnancy, and the Human Life Bill is aimed at taking that decision out of the pregnant woman's hands. Viewed in this way, the Bill is flatly inconsistent with what the Court has stated to be constitutional law, and is thus manifestly unconstitutional.

Had Katzenbach v. Morgan never been decided, and had Roe $v$. Wade held what the Bill's opponents say it did, this would be the beginning and the end of the matter. But Katzenbach v. Morgan has been decided, and decided in a way that, when read in tandem with what the majority actually said in Roe $v$. Wade, ought to give pause to those who find the unconstitutionality of the Human Life Bill a simple matter. For Katzenbach v. Morgan, too, could easily be excoriated in terms much like those used in attack-

Rev. 199, 251-52 (1971) [hereinafter cited as Constitutional Determinations] (discussing ambiguity of legislation seeking to modify Miranda); Sager, Fair Measure: The Legal Status of Underenforced Constitutional Norms, 91 HARv. L. REv. 1212, 1231 (1978) (discussing the problem that by enforcing one right, Congress might intrude on another).

so See, e.g., Cohen, supra note 9, at 606-07; Sager, supra note 29, at 1231-32; see also Cox, Constitutional Determinations, supra note 29, at 247-57 (questioning the need for such a limitation).

31 Segers, Can Congress Settle the Abortion Issue?, Hastings Center Report, June, 1982, at 20 (on file with The University of Chicago Law Review); see also M. PERry, supra note 18, at 135 ("Were Congress to be conceded the power to reverse [Roe v. Wade], we would come to view the Court . . . as a sort of delegate of Congress, much as a court in its common-law role is a delegate of the legislature."). 
ing the Human Life Bill. But it isn't. Although Morgan has its critics, it is widely admired and generally applauded. Therein lies the conundrum. Unless the admiration and applause are directed toward the result, not toward the analysis, the Human Life Bill is not so easily distinguished. And if what is liked about Morgan is the result, then the result of the Human Life Bill-not its implications for the separation of powers-is what the debate ought to be about.

\section{Limiting The Morgan Power}

\section{A. Expansion Versus Dilution of Rights}

Justice Brennan's footnote 10 in Morgan, his gloss on that original footnote in his separate opinion in Oregon v. Mitchell, ${ }^{32}$ and a significant proportion of the scholarship on the Morgan power share a common vision: Something about the enforcement clause of the fourteenth amendment grants to the Congress the authority to make substantive adjustments that expand the scope of rights secured by the fourteenth amendment. The initial definition of those rights might be made by the Supreme Court, but the Congress-whether because of its special fact-finding competence, ${ }^{33}$ because of its unique institutional role in securing individual liberty against state oppression, ${ }^{34}$ or for some other reason-can give the force of law to its disagreement with the Justices. Clever language aside, this is what the majority in Morgan seems to have said, and this formulation has become popular wisdom.

But this formulation rests on two troubling presuppositions. The first is that an observer can readily tell when the congressional action is an expansion of rights. The second is that an expansion of rights for one group will not contract the rights of another. The

32400 U.S. 112, 229, 248 (1970) (Brennan, J., concurring in part and dissenting in part). Justice Brennan, writing for himself and two other Justices, suggested that the Congress might possess the authority to dilute rights found by the Justices if, in an exercise of its special fact-finding competence, it "were to unearth new evidence." Id. at 249 n.31. He was not of course writing for the Court, and in this paper I assume that the Human Life Bill would have to meet the higher standard set in Morgan, not the peculiar gloss placed on the section 5 power by Justice Brennan in Oregon v. Mitchell.

ss See Cox, Constitutional Determinations, supra note 29, at 209-10, 225-26; Cox, Human Rights, supra note 8 , at 101-08. The deference to congressional fact-finding ability was only implicit in Morgan. 384 U.S. at 653-58 (discussing probable factual basis for enactment of $\S 4(\mathrm{e})$ ). Justice Brennan made it explicit in his separate opinion in Oregon v. Mitchell. 400 U.S. at 248,249 n.31.

${ }^{34}$ See Cohen, supra note 9, at 613-16. Professor Cohen's theory is analyzed in greater detail infra at text accompanying notes 81-84. 
conception of a Morgan power that can be used only to expand rights also raises a crucial question: Just what is so special about the expansion of rights? Put otherwise, why establish a constitutional rule that the Congress may overrule all fourteenth amendment decisions except those extending rights to certain individuals or groups?

The history of the fourteenth amendment is either so thin or so negative that no one seriously presses the point that anyone who wrote or ratified the amendment thought that section 5 would grant to Congress any broad power to define the rights protected by the amendment. ${ }^{35}$ And the language of section 5 gives less of a clue than might be thought on whether the power, if it exists, can move rights only in one direction. The congressional authority is to "enforce . . . the provisions of this article." Once one concedes (or contends) that the Congress's enforcement power under section 5 is not limited to the enactment of special procedures for the redress of fourteenth amendment claims, logic alone can dictate no compelling reason that enforcement cannot work in more than one direction. ${ }^{36}$ If the Court has the final word on the meaning of the fourteenth amendment, then to say that the Congress may nevertheless expand the scope of the amendment's protection beyond the reach of the decided cases seems somewhat bizarre.

It ought to go without saying-although history has demonstrated that it does not-that in our constitutional culture, all branches of the government, both state and federal, are bound by the construction placed on the Constitution by the Supreme Court. Whether those who wrote and ratified the Constitution envisioned a form of judicial review in which the courts would deliver constitutional constructions that no one could defy without risking the epithets of "fanatical" or "subversive" may be an interesting question, but it is no longer an important one. The federal and state governments are on notice and have concurred: The Court does have the final say. ${ }^{37}$ Its interpretations of the document may be disputed, but they cannot be overturned unless the Constitution is amended or the Justices themselves reverse their decisions. ${ }^{38}$ To say that the fourteenth amendment grants to the Congress any au-

3s See Bickel, The Voting Rights Cases, 1966 Sup. Cr. REv. 79, 97; Bickel, supra note 27 , at $29-40$.

36 See Cohen, supra note 9, at 606-07; Sager, supra note 29, at 1231-32.

${ }^{37}$ See United States v. Nixon, 418 U.S. 683, 704-05 (1974); Cooper v. Aaron, 358 U.S. $1,18-19$ (1958).

ss Of course, some decisions may simply pass into history, neither overruled nor followed. See Carter, Indeterminate Text, supra note 8, at 852. 
thority whatsoever to alter the content of substantive constitutional guarantees as construed and announced by the Justices is to risk overturning this traditional rule.

Those who support Morgan and oppose the Human Life Bill often seem to invoke and ignore the rule at the same time. The rule is made a firm wall to ward off the Human Life Bill, but the wall is weakened or even burst asunder to explain what the Court did in sustaining section $4(e)$. There is, however, no basis in constitutional language for ignoring the rule in the one case and extolling it in the other. The congressional power is "to enforce." Creating a right that the Court has denied is not "enforcement" of the Court's interpretation; it is revision of that interpretation. So if the Congress may nevertheless expand the provisions through interpretations of its own, then perhaps the Court does not have the final word. If this is so, then why not permit the Congress to "enforce" the fourteenth amendment by limiting the scope of judicial decisions that have, in the judgment of the Members, gone beyond the boundaries of what the amendment protects?

An intuitive response is that ceding to the Congress an authority of such breadth just doesn't sound good. But if the power to limit the scope of the Court's decisions doesn't sound good, then perhaps a power to expand their reach should not sound good either. If the latter sounds good and the former does not, the reason surely has less to do with the language of section 5 or with the structure of the federal government than it does with a value system preferring expansion to contraction of rights and claiming the ability to recognize each when it exists-the symbiotic ideal the limitations of which I have already discussed.

Furthermore, in many instances-the Human Life Bill is only one of them-an assertion by the Congress that a right is being expanded might quickly be met by the petition of a citizen that another right is being diluted. No mere statement that expansion is good and dilution is bad can determine who ought to prevail. The Court, in resolving the dispute, has no choice but to balance the two claims of right one against the other before determining which one should triumph. This, in essence if not in form, is the way the Court proceeded in Runyon v. McCrary, ${ }^{3 \theta}$ in which it rejected the claim that the free-association rights of students and their parents provide a shield against the authority of the Congress to reach private segregation academies. The Court seemed con-

39 427 U.S. 160, 175-79 (1976) (evaluating constitutionality as applied). 
vinced not that no contrary right existed, but that one claim of right was more worthy than the other. ${ }^{40} \mathrm{I}$ certainly do not mean to suggest that the Justices struck the wrong balance in McCrary-on the contrary, I can scarcely conceive of a persuasive argument for any other result--but the reason for my preference has far more to do with my own moral universe than it does with some formal conception of the distinction between the expansion and the dilution of rights.

Three Justices seemed to acknowledge a similar tension in Fullilove v. Klutznick, ${ }^{41}$ which sustained the authority of the Congress to reserve for minority-owned enterprises a given proportion of loans in support of government public works contracts. The problem with the program is common to all racially conscious remedial measures: Plainly, such a "set-aside" provision reduces the likelihood that any particular non-minority-owned entity will obtain a loan, and that reduction is due entirely to the race of the owner. In another context, the legislation might be said to be violating a fundamental right not to be denied a benefit-here, opportunity for participation in the entire program-because of one's race. $^{42}$ But the Morgan power, the plurality concluded, provides a basis for a congressional conclusion that the set-aside provision is necessary to redress pervasive discrimination in the awarding of contracts. ${ }^{43}$ That is a perfectly plausible policy conclusion, but it is also one that permits Congress to use its Morgan power not simply to expand a right, but to determine that one right is superior to another.

10 The same can be said of Brown v. Board of Education, 347 U.S. 483 (1954). See Wechsler, Toward Neutral Principles of Constitutional Law, 73 HARv. L. REv. 1, 34 (1959) (suggesting that the Justices might have given inadequate weight in Brown to the free association rights of white citizens). But cf. Roberts v. United States Jaycees, 104 S. Ct. 3244, 3252 (1984) ("compelling state interests" outweigh the "right to associate for expressive purposes").

${ }^{41} 448$ U.S. 448, 484-85 (1980) (Burger, C.J., joined by White \& Powell, JJ., announcing the judgment of the Court).

${ }^{42}$ Cf. Strauder v. West Virginia, 100 U.S. 303, 308 (1880) (suggesting that all ethnic groups are protected by the equal protection clause); McDonald v. Santa Fe Transp. Co., 427 U.S. $273,285-96$ (holding that antidiscrimination law protects white persons as well as black ones, and concluding that this was the intention of the Reconstruction Congress).

43448 U.S. at 476-78 (opinion of Burger, C.J.); cf. Regents of the University of California v. Bakke, 438 U.S. 265, 367-69 (1978) (joint opinion of Brennan, White, Marshall, and Blackmun, JJ.) (congressional authority under section 5 called broad enough to support racially conscious remedies in the face of arguments that fundamental rights are violated). Of course in Fullilove, as in Morgan itself, see infra note 54, the Justices spoke of superior congressional fact-finding ability even though the Congress apparently did not find any facts. See Drew Days, Fullilove, 96 YaLE L.J. (forthcoming). 
The same seems strikingly true of the decision in Morgan itself. The congressional judgment on whether literacy tests ought to be permitted was the precise opposite of the judicial one, and yet the statute was allowed to stand. The Justices defined the content of the right involved in one way, the members of the Congress in another. The Human Life Bill is usually distinguished, as I have said, on the ground that it conflicts with the right found in Roe, whereas the Voting Rights Act conflicted with no right established by the Court. But this distinction is not based, except in a highly formal way, on the separation of powers. The separation of powers might require that the Congress do nothing inconsistent with the decision of the Supreme Court. The distinction drawn by the Bill's opponents, however, permits the Congress to act inconsistently with the Court's rulings on constitutional meaning, provided that the legislation does not dilute a right that the Court has found. If this is not the distinction, then the Human Life Bill and the Voting Rights Act may have a common separation of powers problem, for both involve a congressional definition of a right in a different way than the Court has defined it. As long as the Morgan power is understood to permit an adjustment in the scope of constitutional rights as defined by the Court, the separation of powers difficulty will remain.

\section{B. Institutional Competence}

Archibald Cox, a longtime defender of Morgan and an incisive critic of the Human Life Bill, has sought to justify the Morgan power through an argument, now widely accepted, couched in terms of the relative competence of the courts and the Congress in the determination and evaluation of facts. ${ }^{44}$ The decision, Professor Cox argues, "follows logically from the basic principles determining the respective functions of the legislative and judicial branches."45 "Whether a State law denies equal protection depends to a large extent upon the finding and appraisal of the practical importance of relevant facts." ${ }^{46}$ Professor Cox would take the usual

14 The Reagan Administration, for example, has described the power in this fashion in a 1982 letter to the Congress: "Congress may enact statutes to prevent or to remedy situations which, on the basis of legislative facts, Congress determines to be violative of the Constitution"-provided always that "Fourteenth Amendment guarantees as recognized by the Supreme Court" are not diluted or abridged. Letter from William French Smith, U.S. Attorney General, to Peter W. Rodino, Chairman of the House Judiciary Committee, at 9 (May 6, 1982).

15 Cox, Constitutional Determinations, supra note 29, at 228.

48 Id. at 228-29. 
judicial deference to legislative judgments of fact and apply it to the fourteenth amendment setting as well, but with the added understanding that, under section 5 , the Court is to prefer federal to state legislative findings when the two conflict. ${ }^{47}$

According to Professor Cox, this deference to the fact-finding competence of the legislative branch supports the conclusion that the Congress generally may expand but not contract constitutional rights declared by the Court. ${ }^{48}$ Using school segregation as an example, he argues that congressional fact-finding is irrelevant once the Supreme Court has decided that the fourteenth amendment of its own force prohibits a state law.

Since the Court . . . will invalidate a State law only if no set of facts which sustains the classification can reasonably be supposed to exist, a decision finding that a State had denied equal protection could not be reversed by Congress because, by hypothesis, there could be no rational support for the congressional conclusion that facts existed to sustain the classification. ${ }^{49}$

In short, the deference is due when findings of fact might make a difference; it is improper when the Court has already determined that they would not-a conclusion the Court is presumed to have reached whenever it holds that state legislation conflicts with individual rights.

This justification for the Morgan power, however, provides no reliable boundary between proper and improper congressional acts. The question whether a particular decision turns on determinations of fact is rarely a simple one. A constitutional fact is not really a fact at all, but a legal conclusion which is stated in a way that makes it sound fact-like. ${ }^{50}$ Thus whether a corporation ${ }^{51}$ or a

47 Id. at 229.

48 But see Oregon v. Mitchell, 400 U.S. 112, 229 (1970) (Brennan, J., concurring), discussed supra note 32 .

- Cox, Constitutional Determinations, supra note 29, at 254; see also Gordon, The Nature and Uses of Congressional Power Under Section 5 of the fourteenth amendment to Overcome Decisions of the Supreme Court, 72 Nw. L. Rev. 656, 671 (1977) (distinguishing "absolute" from "contingent" decisions, on the basis of the relevance of legislative facts to the decision).

so Cf. John Hart Ely, Democracy and Distrust 53 (1980) ("Broad questions of public policy are likely to involve what are called, uncoincidentally, 'legislative facts,' or broad factual generalizations, as opposed to specific 'adjudicative facts." "). A "constitutional fact" may be defined simply as an "adjudicative fact" on which a constitutional decision turns. See Crowell v. Benson, 285 U.S. 22, 60-61 (1932). This distinction between legislative factfinding and "what can at most be called a legislative announcement that Congress believes a state law to entail an unconstitutional deprivation of equal protection" formed an important 
tree $^{\mathrm{s2}}$ or a fetus is a person within the meaning of the fourteenth amendment is an issue of constitutional fact; whether that person visited Monte Carlo last year is not. This distinction matters because, as even Professor Cox acknowledges, "the finding of facts" often "cannot really be severed from their characterization or evaluation for legal purposes and . . . the latter process can hardly be separated from striking a balance between opposing considerations or resolving a question of degree." 33 This makes the border between fact-finding and lawmaking a difficult one to patrol.

Moreover, it is difficult to believe that the Supreme Court that decided Lassiter in 1959 in the midst of the most traumatic period of the civil rights movement, the same Court that was waging a war of attrition against racial segregation (including various forms of voting discrimination), did not know what the Congress later "found": that many states used literacy tests to deny the franchise to their citizens. More important, the Congress arguably never found any facts at all: Section 4(e) of the Voting Rights Act was a floor amendment adopted without specific factual support in the legislative record. ${ }^{54}$ Perhaps, then, the deference to Congress that Professor Cox places at the core of the Morgan power was not constitutional principle, but judicial subterfuge, cloaking the value choice that the time had come to do away with literacy tests.

Finally, Professor Cox's approach does not provide strong support for the conclusion that the Congress has significantly greater power to expand than to dilute rights. ${ }^{55}$ True, the Court may hypothesize that no factual support for a state law can "reasonably be supposed to exist." But the Congress, using its superior factfinding ability, might find evidence that the Court did not believe existed. Suppose that the Congress later finds facts that contravene those underlying the judicial decision in question-for example, the psychological evidence on which the Court (perhaps un-

part of the basis for the dissenting opinion in Morgan. 384 U.S. at 669 (Harlan, J., dissenting).

B1 See, e.g., Wilson v. United States, 211 U.S. 361 (1911); Santa Clara County v. Southern Pac. R.R., 118 U.S. 394 (1886).

${ }^{32}$ Cf. Stone, Should Trees Have Standing? Toward Legal Rights for Natural Objects, 45 S. CaL. L. REv. 450 (1972).

ss Cox, Constitutional Determinations, supra note 29, at 234.

*4 See Morgan, 384 U.S. at 669 \& n.9 (Harlan, J., dissenting).

ss Professor Cox makes clear, however, that he is not committed at all costs to a "oneway-only" version of the Morgan power. See Cox, Constitutional Determinations, supra note 28 , at 255 .

ss Id. at 254 . 
wisely) rested its decision in Brown v. Board of Education..$^{57}$ Arguably, the institutional competence of the Congress in finding facts is such that its subsequent legislation overturning Brown's view of the effects of segregation ought to be valid. ${ }^{88}$ If this example sounds troubling, then so should the next: Suppose that the Congress had expressly found the facts later found by the Brown Court and used them, much as the Court did, to justify a legislative overruling of Plessy v. Ferguson. ${ }^{69}$ Professor Cox's conception of institutional competence provides no basis for distinguishing the two examples. If the first example is troubling and the second is not, the explanation must be the particular value system of the interpreter, not any formal notion of the separation of powers. ${ }^{80}$

Although Professor Cox plainly does not believe that the Human Life Bill is legislation of the sort that section 5 will sustain ${ }^{61}$ his reliance on a deference to congressional competence in fact-finding would probably make advocates of the Human Life Bill quite happy. The constitutional right to an abortion, the Bill's supporters contend, was established only because of the Court's own concession that it was unable to tell when a human life begins. ${ }^{62}$ Roe $v$. Wade, the proponents of the Bill insist, turns critically on the factual difficulty. If the Congress then uses its superior fact-finding ability to determine the beginning point, does the scope of the right to privacy not contract by its own force? ${ }^{\text {s8 }}$ The proponents of the Bill note that in Katzenbach v. Morgan and

s7 347 U.S. 483, 494 n.11 (1954).

s8 At least one contemporaneous observer who believed Brown to be rightly decided nevertheless was quite confident that the Congress possessed adequate authority under section 5 to reverse the decision. See Charles Curtis, Law as large as life: A Natural law por Today and the Supreme Court as its Prophet 116-17 (1959).

s9 163 U.S. 537 (1896).

60 The point is that the interpreter cannot, without crucial and direct reliance on a comparative judgment on the desirability of the results, explain whether the legislative overruling of Plessy would represent societal progress or whether it would constitute an unjustified contraction of the free association rights of pro-segregation whites. The fact that most of us would find the value choice an easy one does not mean that no value choice is involved. See also supra note 40.

11 See Hearings, supra note 13, at 338-44 (prepared statement of Archibald Cox).

62 See Galebach, supra note 13, at 4-5; Hearings, supra note 13, at 264 (prepared statement of John Noonan); id. at 924 (prepared statement of Rep. Henry Hyde).

6s The Roe majority seemed to think so. See 410 U.S. at 156-57 ("If this suggestion of personhood is established, the appellant's case, of course, collapses, for the fetus' right to life would then be guaranteed specifically by the Amendment."). But a strong argument can be made to the contrary. See supra note 23; cf. Guido Calabresi, Ideals, Beliefs, AtTITUDES, AND THE LAW 110-14 (1985) (arguing that the logic of later cases suggests that Roe turned on sexual equality rather than on the "personhood" of the fetus). 
South Carolina v. Katzenbach, ${ }^{64}$ the Court relied expressly on congressional findings of fact to explain why the Congress could declare literacy tests discriminatory even when the Court had not. ${ }^{65}$ The same ability to find facts, the Bill's supporters say, should permit the Congress to alter the scope of the right to privacy through redefining its factual predicates.

The critics usually dismiss this argument as frivolous, and accuse the proponents of the Human Life Bill of misreading (perhaps intentionally) the Court's opinion. For example, in his testimony opposing the Human Life Bill, Laurence Tribe disputed the notion that Roe $v$. Wade rested in any important way on a supposed judicial inability to tell when life begins. "[W] hat [the Court] really meant," he concluded, "was that no State, by adopting its own answer to that question . . . could be permitted to override the fundamental right of the pregnant woman to give an answer for herself." Court said. Wishful thinking aside (for the Court could have written the opinion quite differently than it $\operatorname{did}^{67}$ ), it is Professor Tribe, not the supporters of the Human Life Bill, who appears to have misread the Court's opinion.

The statement in Roe to which he refers reads in its entirety as follows: "In view of all this, we do not agree that, by adopting one theory of life, Texas may override the rights of the pregnant woman that are at stake." Professor Tribe implies, to the pregnant woman's right to privacy, because the statement would then become tautological: "In view of the pregnant woman's rights ... Texas may not override the rights of the pregnant woman." Rather, the "all this" surely refers to the lengthy discussion immediately preceding the quoted sentence. That discussion concerns the inability of the Court to determine-and of society over time to reach consensus on-when human life begins. It is because of this lack of consensus, this dis-

64383 U.S. 301 (1966).

6s See Morgan, 384 U.S. at 652-56; South Carolina, 383 U.S. at 329-33.

68 Hearings, supra note 13, at 243 (statement of Laurence Tribe).

ar See Carter, Roe v. Wade Left Both Sides Open to Science, Wall St. J., Aug. 21, 1985, at 24. For examples of different bases on which the Justices might have supported the rights found in Roe, see Regan, Rewriting Roe v. Wade, 77 MrCH. L. REv. 1569 (1979); Thomson, A Defense of Abortion, 1 Phil. \& PuB. Afr. 47 (1971). The Supreme Court in Roe explicitly declined to entertain the claim "that one has an unlimited right to do with one's body as one pleases," 410 U.S. at 154, and the Justices have subsequently refused an invitation to rest the right to abortion on some other ground, see Akron v. Akron Center for Reproductive Health, 462 U.S. 416 (1983).

${ }^{68}$ Roe, 410 U.S. at 162 (emphasis added). 
sension on a question that is essentially one of fact, that the state may not override the pregnant woman's right to privacy. In fact, the Court itself seemed to believe that if "personhood" were determined to begin at conception, the right to terminate a pregnancy would vanish. ${ }^{69}$

"Personhood" within the meaning of the fourteenth amendment is of course a quintessentially constitutional fact, one that the Court alone may finally decide. But the Court in Roe seemed to base this determination on its answer to another question: whether there existed consensus on the beginning point of human life. This is not a constitutional inquiry. The Court's review of efforts at defining humanity covered not constitutional decisions, but legislative, professional, and societal judgments. ${ }^{70}$ No consensus was found, but a consensus-not a constitutional rule-is what was sought. The Justices might quite properly reserve to themselves the decision on what weight a consensus should carry in the debate over a constitutional right to end a pregnancy, should a consensus be discovered or created. But the distinct inquiry on whether a consensus exists at all quite plainly requires a factual investigation of the sort that a legislature is infinitely more qualified than a court to undertake. The Justices, not the proponents of the Human Life Bill, introduced this nonconstitutional question into the abortion controversy. Once introduced, however, it invites (although it does not require) legislative solution. ${ }^{\text {11 }}$

Roe $v$. Wade simply is not like other controversial pronouncements from the Supreme Court. Its language is far more tentative and cautious than friends and enemies alike generally assert. The frustrating uniqueness of Roe comes in part because no other major constitutional decision of the Supreme Court rests so heavily on a supposed judicial inability to discover a fact. But that inability is only the predicate of the rule; it is not the rule itself. The Court, in other words, has not stated that no one will ever be permitted to determine when human life begins. It has not stated that no consensus will ever develop on when human life begins. An opinion reflecting that conclusion might be a bad one or a good one, but it is not the opinion the Court wrote in Roe. The Court in Roe stated

- See supra note 63.

${ }^{70}$ Roe, 410 U.S. at 129-52 (historical treatment of abortion); id. at 159-62 (historical treatment of beginning of life).

${ }^{71}$ See Chemerinsky, Rationalizing the Abortion Debate: Legal Rhetoric and the Abortion Controversy, 31 Burf. L. REv. 107, 157 (1982) ("The Court's rhetoric in Roe v. Wade makes the arguments for the Human Life Bill at least plausible."). 
only that it does not believe any consensus exists on when human life begins. The legislative branch, whatever its weaknesses, is far more sensitive to the emergence of a fresh consensus than the judicial branch can ever be. ${ }^{72}$ So whether one views it as morally bankrupt or morally imperative, the Human Life Bill represents a perfectly logical effort to resolve the judicial conundrum. The resolution may not be the correct one-indeed, the existence of a potential consensus is dubious and the ideological coloring of the legislation is plain-but it is difficult to see how the reasoning actually contained in Roe $v$. Wade forbids the Congress to try. ${ }^{73}$

Of course, even accepting the reading of Roe offered by proponents of the Human Life Bill, it is not as clear as they claim that the Bill is the product of a bona fide effort to resolve the factual difficulty. My colleague Thomas Emerson, among others, has forcefully contended that the question of when human life begins is one not of "fact," but of "faith, religious dogma, or a fundamental value at the basis of a philosophical system." According to Professor Cox, most of the Human Life Bill "does not even purport to deal with the facts." ${ }^{\text {"75 }}$ Indeed, it is difficult to resist the conclusion that the "findings of fact" in the Human Life Bill are a subterfuge

72 "[W]e may grant until we're blue in the face that legislatures aren't wholly democratic, but that isn't going to make courts more democratic than legislatures." J. ELY, supra note 50 , at 67 (footnote omitted). Democratic or not, many members of the Congress evidently believe they are detecting a developing consensus on fetal humanity. Even if they are correct (and available survey evidence, see supra note 22, suggests that American attitudes about abortion may be more ambivalent than many in the pro-life movement claim), however, supporters of the Human Life Bill and similar legislation should not ignore the distinction between legislative and constitutional facts. A consensus on whether abortion should be permitted or not is largely irrelevant to the determination of constitutional right. Cf. Dworkin, The Forum of Principle, 56 N.Y.U. L. REv. 469, 516 (1981) (the Court should neither "delegate" questions of whether "unborn infants are people" to the legislature nor "accept whatever answer the legislature offers"). But a consensus on whether a fetus is human is precisely what the Court said in Roe might point the decision in the opposite direction. Given the fact that those who are pro-life are far more likely than those who are pro-choice to be politically active, see Jackson \& Vinovskis, supra note 22 , at $68-70$, and that more than half the American public apparently considers the fetus to be a human being, see supra note 22, those who support freedom of choice may yet have before them important tasks of public education. See also K. LuKER, supra note 22, at 236-43 (suggesting that the pro-choice movement should not assume from its success so far that it faces no political problems).

${ }^{73}$ Thus the Congressional Research Service analysis of the Human Life Bill erred in concluding: "The question of when life begins was not decided [in Roe] because it was irrelevant to the legal conclusion and not as a result of a judicially perceived lack of institutional competence." M. Rosenberg \& K. Lewis, Constitutional Authority to Enact a Human Life Statute: A Constitutional Analysis of S. 158, at 25 (1981).

34 Emerson, supra note 17, at 131.

${ }^{75}$ Cox, The Supreme Court, supra note 17, at 711. 
for imposition of a value choice. ${ }^{76}$

Yet attacking the Bill because its findings are inadequate seems a poor substitute for argument on the merits. An attack of this nature implicitly assumes that the Bill would be safe if only the record were stronger. But I have already noted the weakness of the proposition that section 4(e) of the Voting Rights Act was sustained because the Justices were impressed with the congressional findings of fact: There weren't any! The only thing that can explain the preference for one subterfuge over another is the different value choices involved: the Justices (and the scholars) considered the Voting Rights Act a good thing, and they would consider the Human Life Bill a bad one. Argument over good and bad is a legitimate form of political argument, but it has little to do with the special fact-finding competence of Congress.

\section{Remedies}

Some critics have objected to the Human Life Bill-and have tried to preserve Morgan itself-by arguing that Katzenbach $v$. Morgan did not involve any alteration in the substantive content of constitutional rights. Instead, the Court approved no more than a congressional establishment of remedies for the violation of the rights already found by the Court. ${ }^{77}$ Those who make this argument are quite correct in contending that they have found a principled means of striking down the Human Life Bill. Their difficulty is that they have found a principle that cannot explain Katzenbach v. Morgan.

Section 4(e) of the Voting Rights Act does not, on its face, provide a remedy for violation of any constitutional right ever established by the Supreme Court. It is not quite accurate to say

76 This is true in part because although the Bill purports to rest on scientific understandings, the concept of "humanity" may be more a social construct than a scientific one. See, e.g., Grobstein, A Biological Perspective on the Origin of Human Life and Personhood, in Defining Human Life: Medicat, Legal, and Ethical Implications 3, 10 (M. Shaw \& A. Doudera eds. 1983) (biologist concludes that "the concept of person is only partly biological"); Segers, supra note 31, at 21-22 (political scientist concludes that "human beings with human purposes . . . decide when to ascribe personhood"). But see Callahan, The Role of Science in Moral and Societal Decision Making: The Human Life Bill as a Case Study, in DERININg Human Lire, supra, at 314, 318-21 (suggesting that society may define human life in a way that renders the question susceptible to scientific judgment). See generally Carter, The Bellman, the Snark, and the Biohazard Debate, 3 Yale Law \& PoL. REv. 358 (1985) (challenging presumption of deference to scientific expertise even on apparently scientific questions).

77 See, e.g., Appendix to Hearings, supra note 17, at 824-25 (letter of Norman Dorsen); id. at 868-69 (letter of Thomas Emerson). 
that Morgan (or Lassiter for that matter) involved protection or extension of the right to vote; there is no such right available to be protected or extended. ${ }^{78}$ Most frequently, the plaintiff in a "voting rights" case will claim a violation of the right not to be the subject of racial discrimination in voting. After Lassiter one might have said that there was a general right not "to vote" but "to vote if you are literate in English." To speak of protecting that right by.extending it to those not literate in English makes nonsense of the Court's ruling. Something is indeed protected, but it is not the same something that the Court has approved. ${ }^{\text {.9 }}$

The answer to all this may be that the Congress through section 4(e) essentially accepted the invitation that the Supreme Court extended in Lassiter. "Prove to us that literacy tests are a barrier, and they'll go," the Justices wrote in effect. "Here's the proof," the Congress responded. On this model, the right to be vindicated is the right to nondiscriminatory access to the franchise; the ban on literacy tests is remedial because they serve to discriminate.

But even if acceptable as a justification for the result in Katzenbach $v$. Morgan, this model cannot easily serve to distinguish the Human Life Bill. The Congress, after lengthy hearings and detailed findings (be they good ones or not), would be announcing the discovery of a societal consensus against treating the fetus as less than a human being. "We're accepting your invitation," the Congress would say once again-referring this time to the Roe Court's search for just this consensus. "Here's the proof you need." I have already noted that if the Justices can use the slender "findings" supporting section $4(\mathrm{e})$ as a justification for deference, it is not easy to see how they can ignore more detailed congressional findings (whether they be right or wrong) following the extensive hearings on the Human Life Bill.

${ }^{78}$ See Lassiter v. Northampton County Bd. of Elections, 360 U.S. 45, 51 (1959) (the right to vote that is protected by $\S 2$ of the fourteenth amendment is that established by state law).

79 One might avoid this problem by arguing that the Voting Rights Act should never have suspended all literacy tests, but only those actually used for a discriminatory purpose. Although this proposition might be troubling to those who believe in universal adult suffrage, it is analogous to the view that civil rights laws protect individuals, not groups, and that group remedies are therefore inappropriate-the position that the Reagan Administration has urged on the courts in discrimination cases. See Reynolds, Individualism v. Group Rights: The Legacy of Brown, 93 YALE L.J. 995 (1984). Of course, providing remedies on an individual-as-victim model is at best a paradoxical solution to a historical pattern of discrimination against individuals as representatives of groups. See Days, Turning Back the Clock: The Reagan Administration and Civil Rights, 19 HARv. C.R.-C.L. L. REv. 309 (1984). 
To be sure, there is no formal reason that the Court could not reject the findings, because "it is deference and not capitulation which is espoused in Katzenbach." the nature of the record, opponents of the Human Life Bill could note in response to the analogy that the fetus can be assigned no rights because the central thrust of Roe $v$. Wade is that the fetus is not a person under the equal protection clause. But it is not easy to shake the intuition that the argument that the Congress can expand remedies available only to those who are already persons under the amendment is ultimately question-begging. If the Voting Rights Act is deemed remedial and the Human Life Bill is not, the likely reason is a value choice about the relative importance of the claims of right in the two cases. Value choices may have a vital role to play in public argument, sometimes even in constitutional argument, but theories requiring that they be made should not be presented as though the theories are value-free. It simply is not possible to use the argument from remedy to preserve section 4(e), eliminate the Human Life Bill, and avoid discussion on the morality of abortion itself.

\section{Federalism}

Writing about ten years ago, William Cohen tested the leading explanations for Katzenbach v. Morgan and found them wanting. He developed a quite different theory to stand in their place:

A congressional judgment rejecting a judicial interpretation of the due process or equal protection clauses-an interpretation that had given the individual procedural or substantive protection from state and federal government alike-is entitled to no more deference than the identical decision of a state legislature. Congress is no more immune to momentary passions of the majority than are the state legislatures. But a congressional judgment resolving at the national level an issue that could-without constitutional objection-be decided in the same way at the state level, ought normally to be binding on the courts, since Congress presumably reflects a balance between both national and state interests and hence is better able to adjust such conflicts. ${ }^{81}$

so Sager, supra note 29 , at 1230 .

- Cohen, supra note 9, at 614. In his letter opposing the Human Life Bill, Professor Cohen pressed the more straightforward argument that the Congress simply lacks power to diminish constitutional protections established by the Supreme Court. See Appendix to 
Thus it is the federalist nature of the constitutional system-not the content of section 5 itself-that determines the validity of the congressional action. As Professor Sager has pointed out, this theory works only if the Court's interpretations of the equal protection clause are not "understood as exhausting the legal meaning of the clause."82 If they are, then whether or not the Congress has competence superior to that of state legislatures, no fourteenth amendment authority to readjust the substantive content of fourteenth amendment rights emerges.

But even if we ignore this problem, we are faced once more with the need to explain why the congressional power works only in one direction. Professor Cohen resolves the problem by defining it away. The ratchet, as he calls it, turns in only one direction, because the special competence of the Congress only permits it to determine "when decisions traditionally made at the state level should be supplanted by national solutions."8s

Even if correct, his conclusion would pose less trouble than might appear for advocates of the Human Life Bill. They could argue that the fragmented understandings of the different states on the question of when human life begins "should be supplanted by national solutions" at last, thus either recognizing or calling into existence the consensus the Court could not find. To be sure, this argument would be open to challenge: Perhaps the congressional judgment is wrong. But a refusal to defer to the congressional findings places at risk Professor Cohen's entire theory, for a Court could easily second-guess even the conclusion that suspension of literacy tests was necessary. In any case, Professor Cohen's formulation lacks support in the language of section $5 .{ }^{84}$ Just as the case against the Human Life Bill must be based on what the Court actually said in Roe, and not on some more sophisticated argument for the same result, so it should be based on what the Justices have actually said about the powers of Congress, and not on the different and perhaps more persuasive arguments they

Hearings, supra note 17 , at 815 .

${ }^{82}$ Sager, supra note 29, at 1237.

ss Cohen, supra note 9, at 613 .

or Professor Cohen's approach is, however, consistent with Jesse Choper's controversial theory counseling judicial refusal to decide cases involving challenges to congressional exercises of power that are purported to interfere with the sovereignty of the states, see JESSE Choper, Judicial Review and the National Political Process 171-259 (1980), and perhaps consonant as well with Herbert Wechsler's vision of the political safeguards of federalism, see Wechsler, The Political Safeguards of Federalism: The Role of the States in the Composition and Selection of the National Government, 54 CoLum. L. REv. 543 (1954). 
might instead have made.

\section{The Limits of the Discourse: A Transitional Meditation}

Up to this point I have played the game the way that those who call the Human Life Bill unconstitutional seem to believe it ought to be played: by close analysis of the Court's precedents and an effort to apply that analysis to this debate. I say "seem to believe" because the weaknesses I have tried to identify in the arguments against the Human Life Bill suggest that some wishful thinking is interfering with dispassionate analysis. In many cases, policy preferences may be masquerading as constitutional rules. I propose that the analytical difficulties have arisen because the war is being waged (by both sides) on the wrong battleground, that perhaps trying to resolve a struggle over competing visions of rights through the formalistic limitations implied by the separation of powers is a doomed enterprise. Perhaps this is a case for passion, instead of pedagogical distance--as long as one means by passion something other than using subterfuge to fool our opponents rather than change their minds.

I do not mean by this discussion to join the legion of critics who contend that all our modern "rights talk" is essentially incoherent or presents issues incapable of resolution. ${ }^{85}$ That debate, while possibly useful, is quite beside the point I am trying to make. Rather, I only wish to suggest that the form of dialogue over rights that has developed in our own legal culture, a form tying rights to constitutional provisions and judicial precedents rather than to the philosophical predilections of a transient Supreme Court majority, is quite inadequate to find or create ${ }^{86}$ relatively determinate rules for explaining simultaneously why Katzenbach v. Morgan was

ss This debate-at its core a debate about the relationships among law, morality, and politics-is carried on both as part of the search for justifications for particular theories of constitutional interpretation, compare M. PERRY, ThE Constitution, supra note 18, with Brest, The Fundamental Rights Controversy: The Essential Contradictions of Normative Constitutional Scholarship, 90 YALE L.J. 1063 (1981), and, at a more abstract remove, compare Ronald Dworkin, Taking Rights Seriously (1977) with Roberto Unger, KNowledge AND Politics (1975). But the best and simplest statements of the view that moral argument is essentially incoherent remain those of the late Arthur Leff. See Leff, Unspeakable Ethics, Unnatural Law, 1979 Duke L.J. 1229; Leff, Law and Technology: On Shoring Up a Void, 8 OtTAWA L. Rev. 536 (1976).

so All rules, whether created or discovered (in the Constitution or elsewhere), can serve equally to constrain the exercise of power. See Fiss, Conventionalism, $58 \mathrm{~S}$. CAL. L. Rev. 177, 186 (1986) (interpretive rules, even if already "contextualized" and interpreted, can still "constrain the interpretation of another text (the Constitution)"); see also Carter, Indeterminate Text, supra note 8, at 853-65 (advocating creation of narrowing rules). 
rightly decided and why the Human Life Bill is unconstitutional.

One reason that the effort to prove both propositions is so difficult may be that so many of the arguments are essentially ad hoc-that they are being developed for just that purpose. A strategy less detrimental to the enterprise of constitutional theory would be to first derive and defend the moral principle underlying one's value choices, and then apply it openly and honestly to the proposals at hand.

But that approach has grown unfashionable. Nowadays, far too much legislation is opposed not on its merits-through debate over its morality or the effect it would likely have in the real world, and whether that effect is desirable or not-but because of purported constitutional defects. All of us constitutional theorists do it, and so do the legions of activists who rely on our work. Constitutional law is too often reduced to no more than an instrument to be employed in pursuit of political goals. And if law (especially constitutional law) really is no more than the pursuit of politics by other means, then those critics are correct who insist that law is empty at its core. ${ }^{87}$

My faith as a scholar is that the critics are wrong, that constitutional argument is both sensible and necessary. But if the Constitution is more than an instrument to be manipulated, it cannot possibly be the case that everything that is unpopular, even among well-educated elites, is unconstitutional. One of the virtues of living under a constitutional regime is (or ought to be) the possibility that one can make distinct moral and legal arguments, that some things may be constitutionally permissible even though morally repugnant, whereas others may be constitutionally forbidden even though morally required..$^{88}$ If we persist in burying arguments over policy under an avalanche of constitutional jargon, then those who want to speak most closely to the point-whether the proposed legislation is good or bad-will essentially be denied a hearing. The explicitly moral appeals that have the capacity to raise the level of our public debate will be drowned out by charges of unconstitutionality and fanaticism.

87 Typical of the arguments that law is all politics, without coherent structure, are those made by Kennedy, The Structure of Blackstone's Commentaries, 28 Bufralo L. REv. 205 (1979), Rabinowitz, The Radical Tradition in Law, in The Politics of Law 310 (D. Kairys ed. 1982), and Unger, The Critical Legal Studies Movement, 96 HARv. L. Rev. 561 (1983).

${ }^{83}$ For a recent and detailed elaboration of this point, see Schauer, An Essay on Constitutional Language, 29 UCLA L. REv. 797, 812-21 (1982). See also infra note 94 (citing some recent attempts to join normative moral and positive constitutional discourse). 
Classical liberalism, as reflected in the American democratic tradition, is premised on the inevitability of social progress, the vitality of process, and the general (although not absolute) distinction between the legitimacy of a process and the morality of the policies that it produces over the short term. A liberal system may provide a means-for us, judicial review-for invalidating some results of the process. But, by and large, a liberal system will channel public dialogue toward the morality of those results, not the morality of the process itself, unless the process over time fails to reflect the popular will. If the judges whose task it is to measure the results of the process against a higher law-for us, the Constitution-are free to check the process as they choose, to substitute their own view of what the law ought to be for their judgment on what the law is, then those judges, not the process, are producing the rules. ${ }^{80}$ The process, in short, has become irrelevant, and in a way that virtually forecloses public dialogue on the morality of the rules that result. In such a society, there may yet be social progress, but it is no longer liberal democratic progress.

To protect the vitality of process and the role of public dialogue, the rules of liberal adjudication - the rules on which judicial review is popularly and perhaps necessarily defended-require clear interpretive principles to constrain adjudication. ${ }^{80}$ The principle applied in deciding any case must not be selected specially to bring about a desired result, but rather should be derived at a level of generality detached from the needs of the case at hand. This facet of liberal adjudication is captured in Herbert Wechsler's evocation of "neutral principles." The requirement is not that the principle itself be neutral (presumably "neutral principle," if the adjective modifies the noun, is an oxymoron); nor that the process

Bo This proposition has always been central to American constitutional theory. See, e.g., The Federalist No. 78 (A. Hamilton); Alexander Bickel, The Least Dangerous BRANCH (1962). Indeed, it is arguably necessary for all of law. Cf. H.L.A. HART, The Concepr of LAW (1961) (arguing that "rules of recognition" can serve to distinguish law from mere power).

- To say that interpretation should be constrained is by no means to say that it ought to be somehow objective- a goal which, even if desirable (which it may not be), sounds very much like a contradiction in terms. See Dworkin, Law as Interpretation, in THE Politics of INTERPRETATION 249 (W. Mitchell ed. 1983); Dworkin, My Reply to Stanley Fish (and Walter Benn Michaels): Please Don't Talk About Objectivity Any More, in id. at 287. Rather, "[t]he role of judicial objectivity can best be appreciated . . . by seeing constraint by objective sources as itself something valued by courts-as one ingredient in a complex mixture of values." Bennett, Objectivity in Constitutional Law, 132 U. PA. L. REv. 445, 478 (1984); see also Greenawalt, The Enduring Significance of Neutral Principles, 78 CoLum. L. REv. 982 (1978).

91 See Wechsler, supra note 40. 
through which the principle is created be neutral (in the sense that none of the creators care what the principle is); but rather that the act of applying the principle to the case at hand be neutral (in the sense that the principle is not altered because the judge does not like the outcome). ${ }^{82}$

This definitional proposition assumes enormous significance in the debate over the consistency of judicial review with liberal democratic theory. A recurring theme in liberal legal discourse ${ }^{93}$ is the effort to justify much of law based on the process that produced it, while dismissing some properly processed law as immoral, thus unjust, and consequently unenforceable. The effort to show that these dismissals constitute something more than the enforcement of judicial preferences has inspired a major portion of contemporary scholarship on constitutional theory. ${ }^{94}$ The effort to show that they do not has been a centerpiece of the attacks from both the left and the right. ${ }^{95}$ Pending the resolution of this controversy, most observers would probably concede that many of the Court's most lauded decisions-decisions that endorse claims of individual rights by striking down some properly processed law-are supported by reasoning charitably described as obscure.

Perhaps in the short run our legal system and the political system of which it forms a part can survive the application of nonneutral constitutional principles in the evolution of a jurisprudence of rights. Arguments over the Morgan power, however, are

${ }^{22}$ For the debate as to the meaning of neutrality, compare Wechsler, supra note 40 , with Bork, Neutral Principles and Some First Amendment Problems, 47 IND. L.J. 1 (1971). Critics of liberal theories of constitutional adjudication may also take the principle of neutrality as an axiom of the legal system, albeit the system to be deconstructed. See, e.g., MacKinnon, Pornography, Civil Rights, and Speech, 20 Harv. C.R.-C.L. L. REv. I (1985); Tushnet, Following the Rules Laid Down: A Critique of Interpretivism and Neutral Principles, 96 HaRv. L. REv. 781 (1983).

${ }^{93}$ Although my constitutional discussion is limited to what might be called liberal positivist theories, by which I mean those that build on the case law, the privacy right found in Roe $v$. Wade might be supported or opposed-and the Human Life Bill therefore opposed or supported-on arguments that are intended in some sense to transcend, or perhaps refute, conventional liberal legal analysis. Into this category I would place both the feminist jurisprudence supporting abortion rights, see, e.g., MacKinnon, supra note 22, and the essentially religious jurisprudence opposing them, see, e.g., Stephen Krason, Abortion: Politics, Morality, AND THE Constitution 349-92 (1984) (arguing for fetal protection because the fetus possesses a soul).

o4 See, e.g., Bruce Ackerman, Social Justice in the Liberal State (1980); R. DworkIN, supra note 85; JoHN RAwLS, A ThEORY OF JUSTICE (1971).

${ }^{85}$ Attacks from the left I discuss in the various footnotes to this section. Attacks from the right include, for example, Raoul Berger, Government BY Judiciary (1977); Bork, supra note 92; Leedes, The Supreme Court Mess, 57 TEx. L. REv. 1361 (1979); Rehnquist, The Notion of a Living Constitution, 54 Tex. L. Rev. 693 (1976). 
sketched not in the subtle and ambiguous pastels of arguments over individual rights, but in the bold, bright colors of separation of powers and checks and balances and the need to preserve the integrity of judicial review. These are all principles of governmental structure, and as such form the bedrock on which the rest of the constitutional system, including the rights of individuals, is built. As I have argued in detail elsewhere, permitting normative positions to influence the selection of structural constitutional rules will over time prove far more subversive of the rule of law than doing the same with respect to individual rights. ${ }^{96}$ The individual rights clauses are drawn so broadly as to beg to be filled with content from some extra-constitutional source. ${ }^{97}$ The clauses establishing the structure of the government, by contrast, tend to reflect a concrete understanding about the way in which the institutions they create were to interact. In part this is an argument that many of the constitutional provisions setting forth governmental structure are on the whole more determinate than are other parts of the Constitution. In part it is an argument that the courts should choose interpretive rules tending to render them so. ${ }^{98}$ It is difficult-I would say well-nigh impossible-to defend the legitimacy of governance under a system in which no rules are relatively determinate, not even those constituting the system itself. The rules that constitute the system are the rules that create the courts and delineate their function. In interpreting those rules, the judge is both referee and player. ${ }^{9 \theta} \mathrm{A}$ judge playing those dual roles should be self-conscious in her effort to narrow the scope of her own discretion. ${ }^{100}$ Whatever the weaknesses or overindulgences of the Critical Legal Studies' assault on contemporary constitutional theory, there is at the core a proposition that seems to me unex-

98 See Carter, Indeterminate Text, supra note 8, at 853-65.

97 The individual rights clauses often "ha[ve] a distinctly different rhythm and feel," speaking as they do "in terms more lofty, general, and open-ended," so that "[f]aithfulness to the text itself seems to invite a higher level of interpretive generality and a different mode of legal analysis." Amar, supra note 16, at 258 n.169; see also A. BICKEL, supra note 89, at 104-05; Carter, Indeterminate Text, supra note 8, at 849-52. To say this is not to say-how I wish it were!-that I have up my sleeve some perfect means for cabining judicial review under the open-ended and relatively indeterminate fundamental rights clauses.

92 A moderate form of originalism and a faithfulness to the text are among the hermeneutical methods I have in mind, not because they will lead to perfect justice, but rather because they are the most likely to be effective limits on the ability of judges to read their own values into every decision. But see Chemerinsky, Wrong Questions Get Wrong Answers: A Reply to Professor Carter, 66 B.U.L. Rev. (forthcoming).

" See Carter, Judicial Power, supra note 27, at 1367.

100 See Carter, Indeterminate Text, supra note 8, at 853-72 (relating this argument to the effort to justify liberal conceptions of judicial review). 
ceptionable: If even the structure of government is generally indeterminate and malleable as judges change their minds, then most of what we call constitutional law is simply judicially created policy, and the claim for a rule of constitutional law is a rather nasty joke. ${ }^{101}$

Opponents of the Human Life Bill who assail it as a violation of the separation of powers, but who want nevertheless to preserve the result in Katzenbach v. Morgan, must be prepared to buttress their constitutional arguments with supporting principles that do not rely for their force on whether the person applying them thinks Roe $v$. Wade was rightly or wrongly decided. If the Human Life Bill is challenged on separation of powers grounds-grounds derived from the constitutional structure of government-then the distinction between the Bill and section 4(e) cannot, under the rules of liberal adjudication, rest ultimately on the pro-choice predilections of a majority of the Justices. If one is desirable and the other is not and the reason is that one protects something the critic likes and the other does not, then the rule is neither as determinate nor as neutral as the academic critics of the Human Life Bill would have members of the Congress believe. If the distinguishing rule does indeed require hostility toward efforts at banning abortion, then it is not a rule about the separation of powers.

This is the reason I suggested at the beginning of this section that the separation of powers is a poorly chosen battleground for this controversy. Perhaps the parties should fight instead over the real issue between them: Whether abortion should remain a matter for private choice. Thus, saving Morgan-and saving classical concepts of constitutional adjudication-requires stepping back from the bold separation of powers arguments usually offered to distinguish section $4(\mathrm{e})$ of the Voting Rights Act from the proposal for a

${ }^{101}$ See id. at 829-30. Constitutional theorists (or perhaps they are better described as anti-theorists) associated with the Conference on Critical Legal Studies press the more generalized argument that any indeterminacy of constitutional rules threatens legitimacy of the constitutional structure. See, e.g., Parker, The Past of Constitutional Theory-And Its Future, 42 Oно Sr. L.J. 223 (1981); Tushnet, Darkness on the Edge of Town: The Contributions of John Hart Ely to Constitutional Theory, 89 YALE L.J. 1037 (1980). But liberal theory may be able to survive this critique, in part because relatively determinate structural provisions can help justify relatively indeterminate rules for construing provisions on individual rights. See Carter, Indeterminate Text, supra note 8.

Mark Tushnet has pressed the argument that the clauses that establish the structure of the federal government may not be fairly described as even relatively determinate. See Tushnet, A Note on the Revival of Textualism in Constitutional Theory, 58 S. CAI. L. REv. 683 (1985). Even if he is correct that it is possible to imagine an interpretation of a clause apart from the obvious one, it is not necessarily the case that the courts cannot or should not select interpretive rules rendering the structural clauses relatively determinate. 
Human Life Bill, thereby gaining a perspective sufficient to consider the matter from a different angle. It requires as well a willingness on the part of the defenders of section 4(e) who are also opponents of the Human Life Bill to shift their ground, openly to argue right and wrong, rather than to disguise moral preference as constitutional law. Following the back step, following the shift, it should be possible to reconstruct the Morgan power in a way more consistent with both the liberal democratic value of public dialogue and the separation of powers that underlies our constitutional system.

\section{The Morgan Power as Liberal Ideal}

\section{A. Morgan as Dialogue}

The spirit of a decided case involves much more than the Court's reasoning, and the spirit of Katzenbach v. Morgan involves much more than the meaning of Justice Brennan's limiting footnote. Whatever the other lessons of legal realism, one aspect of its teaching is clear: A court's stated explanation for its decision does not necessarily capture the reasoning process the court has actually undertaken. Similarly, the reasons Morgan was rightly decided may have only the most tenuous connection with the reasons articulated by the majority.

Some years ago, Alexander Bickel described an "endlessly renewed educational conversation" between the Justices of the Supreme Court and the public that must decide whether to obey their edicts, concluding with the admonition that "it is a conversation, not a monologue."102 In Professor Bickel's vision, the Court's many constituents, including the public and the Congress, respond by words and actions to the Court's decisions-and the Court must listen to the response. ${ }^{103}$ The Justices do not necessarily reverse themselves when their decisions are unpopular ${ }^{104}$-no functioning guardian of fundamental rights could justifiably do so. But they are certainly aware of opposition when it exists.

102 Alexander Bickel, The Morality of Consent 111 (1975). For an effort to describe the political philosophy underlying Bickel's work, see Kronman, Alexander Bickel's Philosophy of Prudence, 94 YALE L.J. 1567 (1985).

${ }^{103}$ Cf. Wellington, The Nature of Judicial Review, 91 YaLE L.J. 486, 516 (1982) ("It is a wise court that pays attention to the community-not out of fear, but out of obligation."). I would emphasize, however, that an obligation to listen hardly translates into an obligation to concur.

104 See S. Goldman \& T. Jahnige, The Federal Courts as a Political System 229-68 (1st ed. 1971). 
A dialogic theory of this kind may be the key to understanding the Morgan power. Writing several years after Professor Bickel did, when the Congress was showing signs that it would make more use of the Morgan power, Robert Burt made a similar suggestion about the scope of and the justification for congressional authority under section 5. The Supreme Court in Katzenbach v. Morgan, Professor Burt suggested, did not really define a power to override the Court's decisions, but rather offered an invitation to poke about the margins, to work "around the edges" of the doctrines proclaimed by the Court. ${ }^{105}$ The Court, in Professor Burt's theory, would issue the broad pronouncements; the details of application could be worked out in "an ordered dialogue between Court and Congress." 106 In this way, society could progress without leaving to the Court the unpalatable and politically risky task of dealing with the minutiae of transforming its judgments into working policy. ${ }^{107}$

The theory set out by Professor Burt is quite appealing, because instead of relying on any highly formalistic vision of separation of powers and neutral principles, it envisions a continuing process through which the Court and the Congress "speak" to one another. But his theory makes too little of what the Court permitted in Katzenbach $v$. Morgan. That case involved no mere marginal adjustment in the content of previously declared rights. It was, and should be admitted to have been, a flat congressional override of what the Court had previously announced as constitutional law. Nevertheless, Professor Burt's dialogic view of Morgan may possess a healthy degree of explanatory power, once it is freed from the arbitrary limitation that the dialogue is joined only at the margins.

The missing dimension is supplied by returning to Professor Bickel's original vision of the dialogue. The role of the Supreme Court in that vision is not merely to monitor the legislature's tinkering with its decisions, but to pay attention to the depth of opposition as well. Section 4(e) of the Voting Rights Act fits this model more easily than it does any of the complicated separation of powers theories that are usually advanced to justify Morgan and limit its scope. The literacy test prohibitions did more than simply engage the Justices in debate: They announced a congressional judg-

${ }^{105}$ Burt, Miranda and Title II: A Morganitic Marriage, 1969 S. CT. Rev. 81, 129-34. Others have also suggested that the Morgan power is most usefully considered as applicable only at the margins, not at the core. See, e.g., Sager, supra note 29, at 1239-40.

${ }^{108}$ Burt, supra note 105, at 134.

${ }^{207}$ Id. at 132-34. 
ment that the Court was simply wrong. Whether the judgment was one about law or fact or morality is quite beside the point; the Congress wanted literacy tests to go and was quite willing to say so through affirmative legislation. Absent that legislation, there would have been no Katzenbach $v$. Morgan and thus no debate.

The Human Life Bill fits the same model. Some of the Bill's proponents insist that they do not really believe that the Congress possesses the authority to reverse Roe $v$. Wade by affirmative legislation. In fact, they may even concede that under some reasonable readings of Roe the proposed Human Life Bill is unconstitutional on its face. ${ }^{108}$ They nevertheless support the bill for what they call its symbolic value: It represents an opportunity to put the Court on notice that the Congress of the United States, as a separate, coequal, and much more representative body, considers abortion the killing of a human being and Roe $v$. Wade therefore wrongly decided. ${ }^{109}$ In so doing, the proponents explain, they seek to engage the Justices in a conversation, to force the Court to acknowledge, even when striking down the bill, that it is acting in the face of growing national opposition. ${ }^{110}$ In short, the proponents of the Human Life Bill may implicitly be endorsing a dialogic interpretation of Morgan: They want to offer the Court a chance and a reason to overrule Roe.111

The literature generally dismisses this argument out of hand. Samuel Estreicher, one of the most articulate critics of the Human Life Bill, points out that the proposed bill represents far more than a "mere declaration" of congressional opinion: Its supporters envision enforcement of the Human Life Bill through the adminis-

${ }^{108}$ I take this to be conceded in Stephen Galebach's testimony in support of the Bill. See Hearings, supra note 13 , at 200.

108 See, e.g., id. at 278 (statement of William Van Alstyne) (suggesting that the Bill "is frankly a stalking horse . . . to dramatize the depth of private feeling that attended the decision in Roe v. Wade" and that it is appropriate for Congress to "use the newsworthiness of proposed but futile . . . legislation for such advertising purposes"); id. at 925 (prepared statement of Rep. Henry Hyde) ("I see nothing wrong and much right about passing a Human Life Bill and giving the Court an opportunity to reconsider Roe v. Wade," even if the legislation is deemed unconstitutional).

${ }^{110}$ See id. at 200 (statement of Stephen Galebach).

111 Although Michael Perry once proposed a similar dialogic model of the relationship between the Court and the Congress, he overlooked the possibility that the Congress might play its part in the dialogue by enacting an arguably unconstitutional statute, concluding instead that "[s]uch a change in the relationship between Congress and the Court would tend to undermine the very inter-institutional tension-the dialectic interplay between Court and Congress-that is the reason to value noninterpretive review in the first place." M. PERRY, supra note 18 , at $135-36$. 
tration of restrictions on the practice of abortion. ${ }^{112}$ Thus, he concludes, the bill's supporters "must be claiming that without the Court's cooperation, Congress has authority to authorize restrictive regulation of abortion." ${ }^{113}$ In other words, the claim that the bill forms part of a dialogue with the Court is simply a sham.114

But this criticism is somewhat wide of the mark. Naturally the proponents of the Human Life Bill envision doing all in their power to prevent abortion; that is what motivates their support. If, however, the Court is to be engaged in a dialogue, it must be presented with a real case or controversy. What Professor Estreicher would apparently prefer-a declaration that the Congress believes that human life begins at conception, devoid of enforcement apparatus-probably would raise no justiciable issues because it would injure no one. As advocates for the mentally disabled learned in the Pennhurst case, a congressional effort to legislate through imprecation is nothing more than a statement of opinion, and a wholly ineffective statement of opinion is a form of opposition the Justices can easily ignore. ${ }^{115}$ In a continuing dialogue between the Congress and the Court, the form in which the

112 Estreicher, supra note 17, at 346 \& n.28.

113 Id. at 346.

${ }^{134}$ Another version of the "sham" argument has been pressed by my colleague Lea Brilmayer, who contended in written testimony opposing the Human Life Bill that the proposal seeks to authorize the states to do what the Congess itself could not constitutionally do--ban all or most abortions-and that no Supreme Court decision has ever authorized the Congress to act in that fashion. See Brilmayer, The Human Life Bill, the Bill of Rights, and the Congressional Enforcement Power under Section 5 of the Fourteenth Amendment, in Appendix to Hearings, supra note 17, at 793; see also Hearings, supra note 13, at 248-50 (prepared statement of Laurence Tribe) (similar argument). Professor Sager made a similar point long before anyone suspected that a Human Life Bill was afoot. See Sager, supra note 29, at 1240 (arguing that the Morgan power cannot authorize the states to do anything that the Court would forbid).

None of this, however, weighs adequately the peculiar nature of the majority opinion in Roe and, in particular, the seeming judicial invitation to the political branches to search for consensus on when life begins. See supra notes 62-73 and accompanying text. If the supporters of the Human Life Bill are right to read Roe as they do-and certainly their argument is not frivolous-then the Bill does not authorize the states to do what the Congress could not. On their reading of Roe and Morgan, the Congress could, given proper factual determinations, enact legislation directly restricting the exercise of the rights found in Roe. In other words, according to its proponents, the Bill would authorize the states to do no more than the Congress itself may do.

126 See Pennhurst State School \& Hosp. v. Halderman, 451 U.S. 1 (1981) (holding that congressionally approved "bill of rights" for the mentally disabled creates no substantive rights). A dialogical view of the relationship between Congress and the Court might have led to a different result. See Burt, Constitutional Law and the Teaching of the Parables, 93 YALE L.J. 455, 497 (1984) ("Even accepting the premise that congressional intent was unclear here, the Court should have welcomed and reached out to find Congress's constitutional interpretive authority in this matter."). 
opposition makes itself manifest may matter a great deal; some forms are more easily ignored because they are more easily contrived. But the dialogue envisioned by the proponents of the Human Life Bill is one in which each side uses all the resources at its disposal. ${ }^{116}$

The force with which the American people (and just as important, those who govern them) are socialized into obedience to the rule of law as articulated by the Supreme Court is tremendous. Children are taught obedience to law from early in their school years; as adolescents, they learn in civics that the Supreme Court authoritatively interprets the Constitution; as adults, they are warned that disobedience to the courts is subversive. This general respect for law, even if the law is considered unjust, is probably the most powerful bulwark the American legal and political culture offers against revolution. This socialization and the concomitant responsibilities it surely carries are the most powerful weapons the Court can bring to bear in any struggle with the Congress. Although the public may be angry, the Justices, if they possess sufficient fortitude, will nearly always win-at least for the near term.

But the fact that the Congress is likely to lose its battle to convince the Court (if it is a fact) cannot be the argument against undertaking it. The point is that by enacting a statute that the Supreme Court will likely find patently unconstitutional, the Congress may nevertheless play a role in constitutional dialogue. This is surely what Abraham Lincoln had in mind when, in debate with Stephen Douglas, he declined to assign to the Dred Scott deci$\operatorname{sion}^{117}$ the force some claimed for it:

We do not propose that when Dred Scott has been decided to be a slave by the court, we, as a mob, will decide him to be free. . . . [W]e nevertheless do oppose that decision as a political rule'. . . which shall be binding on the members of Congress or the President to favor no measure that does not actu-

116 To better understand why the mere adoption of a congressional resolution of disagreement would not be an adequate substitute for affirmative legislation of this nature, it might be useful to imagine a member of Congress who has voted in favor of a nonbinding resolution urging the overturning of Roe. The representative goes home to her district and explains to a pro-life group, "I strongly oppose abortion, of course, but this was all I could do, because the Court has ruled." She then goes across the street and tells a pro-choice group, "Although I am personally opposed to abortion, I pledge that I will not vote in favor of any unconstitutional efforts to circumvent the decision." If the Congress risks nothing because it does nothing, then the dialogue is not really joined in the way that it is when members of Congress take the risk, go out on the limb, and adopt the affirmative legislation.

117 Dred Scott v. Sandford, 60 U.S. (19 How.) 393 (1857). 
ally concur with the principles of that decision. ...W We propose so resisting it as to have it reversed if we can, and a new judicial rule established upon this subject. ${ }^{118}$

His argument was not for mob justice or revolution. His method, after all, would not succeed unless the Justices changed their minds.

Thus the torturous judicial and academic searches for authority to explain and rules to limit the scope of the congressional authority enunciated in Katzenbach v. Morgan may be somewhat misguided. After all, a sufficiently determined Supreme Court might have countered section 4(e) with an opinion boiling down to this: "Look, we told you before that literacy tests do not violate the fourteenth or fifteenth amendments, so quit trying to find a way around our decision." Instead it said in effect: "Well, okay, if you're really sure that literacy tests are so bad, we're content to go along." Oregon $v$. Mitchell, ${ }^{119}$ in which the Justices sustained the nationwide suspension of literacy tests, might be explained the same way. To take a contrary case, in Mississippi University for Women $v$. Hogan, ${ }^{120}$ wherein they rejected a claim that the Congress possessed and had exercised authority under section 5 of the fourteenth amendment to permit the states to operate single-sex nursing schools, the Justices were plainly unpersuaded that sexually segregated schools run by the state were a good thing.

Following the same reasoning, in the unlikely event that the Congress were to enact a Human Life Bill, judicial independence would not necessarily be threatened: The Justices could certainly strike the legislation as patently unconstitutional. On the other hand, the Justices might vote to sustain it. Were they to do so, the best explanation would be not that they had yielded their constitutional prerogative, but rather that they had been convinced by the reasoning (or the depth) of the congressional opposition.

If all of this is so, then the place of the Morgan power in the dialogue between the Court and its constituents should be plain. I earlier outlined the ideal of symbiotic progress, in which the Congress and the Supreme Court take turns leading the way toward a better future. An exercise of the Morgan power may fit into that progression in a special way, as the Congress's most effective tool for expressing its strong disapproval of a judicial decision ac-

118 Politicat Debates Between Abraham Lincoln and Stephen A. Douglas 299 (1895) (Lincoln's speech of Oct. 13, 1858, at Quincy, Illinois).

119400 U.S. 112 (1970).

120458 U.S. 718 (1982). 
cepting or rejecting a claim of fundamental right without risking the Court's legitimacy, hence the Constitution's, hence ultimately its own.

To be sure, the Congress might try to do the same thing by enacting apparently unconstitutional legislation under the authority granted by any number of constitutional provisions, but proceeding under section 5 reduces the likelihood that the moral authority of the Court will be diminished should the Justices alter their decisions. As clever lawyers, the Justices can always accommodate the congressional action without unduly expanding congressional authority. Justice Brennan tried to do exactly this through his footnote 10 in Morgan. Furthermore, reliance on the special power granted to the Congress under the fourteenth amendment is consistent with the distinction I have drawn here and elsewhere between types of constitutional provisions. When the decision that the Congress calls into question is one regarding governmental structure, flowing therefore from the document's structural provisions, the Court may properly decline to enter the dialogue. By hypothesis, the Justices construe the Constitution's structural clauses under a set of rules chosen to channel their discretion narrowly. But under the open-textured clauses, where there is less to guide the Court in its decisions, it is particularly important that the Congress be able to engage the Court in dialogue without being accused of defiance. The Court may reaffirm its decisions, and in most cases-including, I suspect, Roe $v$. Wade-it presumably will, but it must do so with the knowledge that there exists a congressional consensus adequate to bring about affirmative and contrary legislation. Denying to the Congress the authority to enact the legislation is in a sense to deny to the Justices the knowledge that this contrary consensus exists. Permitting the legislation, even when it might subsequently be overturned, forces the Court to make an informed choice. And in the continuing dialogue, informed choices are the ones that matter most.

This understanding of the Morgan power seems entirely consistent with the separation of powers. There is no violation of the rule of United States $v$. Klein, ${ }^{121}$ because the Congress is not requiring the courts to decide cases in a particular way. After all, the Supreme Court still has the power to say "No," thus preventing enforcement of the congressional plan. No matter how many plans are presented, the Court may strike all of them down until the 
Congress gets tired of trying, as Texas apparently did in the "white primary" cases. ${ }^{122}$ Or the Justices may instead be the first to tire and may reverse themselves, as they apparently did during the New Deal. ${ }^{123}$ But as long as the decision rests with the Justices alone, a judicial change of mind cannot be barred by separation of powers, even when the change is brought on by congressional or public pressure. The doctrine of separation of powers insulates the courts from force, not from persuasion.

I have argued elsewhere that the checks and balances should be viewed as a dynamic system, one in which all the branches, including the judicial branch, struggle for recognition, for authority, and perhaps for victory as well. ${ }^{124} \mathrm{I}$ have stressed the need to limit the ability of each branch to create what might be called "fresh checks," methods of controlling the other branches that were not apparently in the contemplation of those who designed the system. ${ }^{125}$ But the Morgan power that I have described certainly is no fresh check. On the contrary, the exercise of the power involves ordinary legislation-the object the Constitution most plainly empowers the Congress to undertake-and legislation under a clause, section 5 of the fourteenth amendment, that plainly contemplates a special congressional role. ${ }^{126}$ Legislation, or attempts at legislation, are surely the most important weapons the Congress can bring to bear in this continuing battle to check and balance. In fact, if the Congress can never propose apparently unconstitutional legislation, it is difficult to see how the Court will ever have the opportunity to overrule a decision the Justices later decide was unwise. ${ }^{127}$ In a dynamic system, the overruling of a past decision may be taken to mean that the Justices have chosen to back down. In an ultimately political struggle, however, there is no reason that one branch-even one as popular among legal scholars as the judi-

${ }^{122}$ See Nixon v. Herndon, 273 U.S. 536 (1927) (striking down Texas statute); Smith v. Allwright, 321 U.S. 649, 658-61 (1944) (reciting Texas's efforts to resist the Court's decision).

${ }^{123}$ See C. BLACK, supra note 1, at 60.

124 See Carter, Judicial Power, supra note 27, at 1372-84; Carter, The Constitutionality of the War Powers Resolution, 70 VA. L. REv. 101, 112-16 (1984).

${ }_{128}$ See Carter, Indeterminate Text, supra note 8, at 862-63; Carter, Judicial Power, supra note 27 , at 1364-72, 1394-99.

${ }^{128}$ Section 5 of the fourteenth amendment, like the enforcement clauses of the thirteenth, fifteenth, nineteenth, twenty-third, twenty-fourth, and twenty-sixth amendments, grants to the Congress an explicit power to enforce the Constitution itself. The more common grants of authority-specifically, those listed in article I, section 8-do enable the Congress to act, but not in furtherance of protecting rights that the Constitution itself might be said to hold dear.

127 See Raoul Berger, Congress v. The Supreme Court 194-97 (1969); Hart, Professor Crosskey and Judicial Review (Book Review), 67 Harv. L. Rev. 1456, 1457-58 (1954). 
ciary-must always be the winner. ${ }^{28}$

\section{B. Implications of the Dialogue: The Morgan Opportunity}

Viewed in the way that I have described it, as the chance to force the Justices to rethink what they have done, the Morgan "power" is probably misnamed; Professor Burt has said that we should think of it as the Morgan "invitation." 129 If an invitation was extended, however, the invitation came from the Congress, not from the Court, and the decision in Morgan was the Court's signal that the invitation will sometimes be accepted. In this sense, Morgan involved less a power or a conscious invitation than it did an opportunity-the opportunity for the Supreme Court to reconsider its approach in resolving a difficult societal problem.

The congressional invitation, the judicial opportunity, is brought into existence only when the Congress enacts legislation that seems to fly in the face of the Court's precedents. But congressional action of that kind hardly represents the exercise of some special "power." The Congress always possesses the raw power to enact an unconstitutional law in the very formal sense that if a majority of its members vote "Yes," then the statute will go on the books, even though it might never be enforced and would probably be struck down. To describe that as an exercise of a legislative power, however, is to play a game with words. "The Congress has the power to do $X$ " in contemporary constitutional dialogue means "the Congress acts constitutionally when it does $X$." Section 4(e) of the Voting Rights Act became constitutional only because the Supreme Court took advantage of the opportunity offered it by the Congress to overrule, albeit silently, the essence of Lassiter. Similarly, proponents of the Human Life Bill want to offer the Justices the opportunity to overrule, even silently, the essence of Roe. If judicial acceptance of the offer seems unlikely, the prediction simply serves as additional evidence that the word "power" is, in this context, misused: There is no Morgan power.

The implication of the Morgan opportunity, as it should thus be called, is that members of the Congress ought sometimes to vote in favor of statutes they believe will not stand up under judicial scrutiny. In a political culture dominated by law, the argument

128 This dialogic conception is discussed in greater detail in Carter, The Right Questions in the Creation of Constitutional Meaning, 66 B.U.L. REv. (forthcoming).

129 See Burt, supra note 105, at 81, 113-14. Irving Gordon has suggested a similar metaphor to illuminate the relationship between the Court and the Congress. See Gordon, supra note 49 , at $704-05$. 
"The courts would declare this statute unconstitutional" carries substantial weight in congressional debate prior to a bill's passage. This is as it should be, for a Congress determined always to ignore the will of the courts would, in American terms, be a lawless one. But that is not the same as saying that whenever a member of that Congress decides to vote her conscience rather than her prediction of what a court would do, the fabric of American society is threatened. ${ }^{130}$ Only a fanatic would try to defy every court decision contrary to some individual constellation of values, but most of us do (and all of us should) have some values we hold so dear that the fact that "process" has produced a contrary result will not long detain us. True, the effort to shape these values into policy in defiance of legal institutions often leads to reaction or revolution, but in a society which, as ours should, emphasizes change and evolution, that effort is far more likely to lead to progress-as it did in Katzenbach v. Morgan.

Whether the enactment of the Human Life Bill would also lead to social progress is a matter that cannot be decided by legal analysis, but only through each individual's search of his or her own values. A negative answer to that inquiry, however, hardly dictates the conclusion that the Bill must therefore be unconstitutional. Just as some of the Bill's opponents have concluded that abortion is wrong but the legislation is nevertheless unconstitutional, it is possible to conclude that abortion is best left to individual choice but that the Bill does not violate the separation of powers. Unfortunately, in American political culture, opinions on the constitutional merits of a proposal are frequently mistaken for-or translated into-views on its wisdom or folly.

Too often in our political dialogue, we speak as though the Constitution and the decisions explicating it constitute the whole of public morality. This is a dangerous view, because it gives fallible (sometimes pernicious) institutions an undeserved centrality in the moral universe. Liberal political theory demands no such conclusion. Rules are not good rules merely because they accord with authority, and proposed rules are not bad ones merely because au-

${ }^{230}$ For different positions on this issue, see Brest, The Conscientious Legislator's Guide to Constitutional Interpretation, 27 STAN. L. REv. 585 (1975) (suggesting that a proper understanding of the significance of prior judicial actions should guide voting in the legislature); Fisher, Constitutional Interpretation by Members of Congress, 63 N.C.L. REv. 707 (1985) (members of Congress have sufficient staff to enable them to make independent constitutional assessments); Wechsler, The Courts and the Constitution, 65 CoLUm. L. Rev. 1001, 1008 (1965) (a state legislature may offer an unconstitutional statute, but should eventually accede to the Court's insistence on its unconstitutionality). 
thority disagrees. Yet in America, liberalism, with its focus on the rule of law, has come to shy away from public moral discourse. At least in part as a result, the United States lacks a coherent tradition of public morality, and people who insist on discussing morality (which in much of the Western world is central to any debate over public policy) are often dismissed as dangerous fanatics.

These developments have contributed to an unfortunate facet of the modern legislative processes. Every controversial proposal generates legions of scholars to testify on whether it does or does not conform to past judicial decisions. Yet if public debate ignores questions of morality (or grants those questions only a subordinate status), then real individuals with views on the wisdom or folly of the proposal are reduced to the status of nonautonomous agents-a status that liberalism rightly condemns. When immoral legislation is proposed, its opponents do a disservice to public discourse-and to their own cause-when they couch their moral arguments as constitutional ones. The Right has in recent years been quicker than the Left to recognize that in the battle for public opinion, when one side argues morality and the other argues constitutional law, the, side with only the Constitution to offer finds itself with the more difficult struggle.

That opponents of the Human Life Bill resist the invitation to moral discourse might suggest a fear of being bested, but it is hardly the case that no nonconstitutional arguments against the Bill are available. Even one who is troubled by an unencumbered right to obtain an abortion might pause and consider why the Congress should place on a woman who is pregnant a greater burden to support another life than we place on others in society. ${ }^{131}$ The debate over abortion, however, is frequently carried on as though fetal personhood is the only dispositive issue, as though it really is self-evident-as the Roe majority seemed to think-that the right to end a pregnancy could not co-exist with a belief in fetal humanity. Yet one could simultaneously accept that the fetus is a human being and that the state ought not force a woman to carry it. ${ }^{132}$ Even if the critic of Roe is unconvinced by any of this, there re-

181 See Tribe, The Abortion Funding Conundrum: Inalienable Rights, Affirmative Duties, and the Dilemma of Dependence, 99 HARv. L. REv. 330, 337-38 (1985); Regan, supra note 67 .

132 See Law, Rethinking Sex and the Constitution, 132 U. PENN. L. REv. 955, 1021 (1984); Thomson, supra note 67; cf. Note, The Creation of Fetal Rights: Conflicts with Women's Constitutional Rights to Liberty, Privacy, and Equal Protection, 95 Yale L.J. 599, 608-09 (1986) (suggesting that forced medical treatment of a pregnant woman in the interest of protecting fetal life might be harmful to the well-being of the woman). 
mains all the slippery slope problems attendant on a definition of a fetus as a human being, problems only partly captured by the image of prosecuting as child abusers women who smoke or use drugs during pregnancy. ${ }^{133}$ The point of this is not that these arguments would necessarily convince; only that these, and others like them, are available to those who oppose the Bill and are at least as weighty as the somewhat shaky constitutional case. If opponents of the Human Life Bill and similar proposals prefer to make the constitutional argument instead, they will inevitably face suspicion that they are simply afraid of moral debate. That is why the prochoice forces ought not to neglect the argument that congressional action to restrict abortion might be wrong not because it is unconstitutional but because it is immoral. ${ }^{134}$

\section{CoNCLUSION}

"The crucial point," Professor Bickel argued in The Morality of Consent, "is that we engage in a contest of wills." bach $v$. Morgan, the congressional will was sufficiently strong that the Court was persuaded to abandon its own stated position. In the next case, especially if it involves the Human Life Bill, the contest might be decided the other way. But as long as the Morgan opportunity exists, the contest-and the dialogue that underlies it-will (and should) go on.

The Human Life Bill, in short, might be a poor idea and might, if enacted, be declared unconstitutional by the courts. Those characteristics do not necessarily differentiate it from the Voting Rights Act of 1965. The instinct that the two are different surely stems from an instinct about the Court - that the Justices are far more determined to preserve the right of a pregnant woman to decide whether to proceed with her pregnancy than they ever were determined to preserve the authority of a state to bar illiter-

13s Cf. Beal, "Can I Sue Mommy?" An Analysis of a Woman's Tort Liability for Injuries to Her Child Born Alive, 21 SAn Diego L. REv. 325 (1984). For a comprehensive listing of other obstacles that await down the slippery slope, see Westfall, Beyond Abortion: The Potential Reach of a Human Life Amendment, in Derining Human Life, supra note 76, at 174.

${ }^{134}$ Not all opponents of the Human Life Bill have sidestepped moral argument. For example, Judy Collins, testifying in opposition to the Human Life Bill, eschewed legal argument, presenting instead the views of many who had been involved in one way or another with decisions about and performances of abortions. See Hearings, supra note 13, at 974-95. She obviously is not a constitutional scholar, but those who are do not necessarily possess special expertise if, as I suggest, the potential constitutional infirmities of the legislation are not by themselves sufficient reason (and cannot possibly be the best reason) to defeat it.

${ }^{135}$ A. Bickel, supra note 102, at 111. 
ate voters from the franchise. The distinction, in other words, stems from a reading of the minds of the Justices, not from an interpretation of the lines of the text, and the statement that the Human Life Bill is patently unconstitutional is little more than a prediction-or a plea-that the Justices would find it so. ${ }^{136}$

Predictions-and pleas, too-play a crucial role in the continuing dialogue between Congress and the Supreme Court; so do the other efforts by Congress to change the Court's mind. Katzenbach $v$. Morgan may best be read as no more than an implicit judicial acknowledgment of the truth of both these propositions.

${ }^{136}$ In the end, then, we get back to Holmes, and perhaps the most important of his many aphorisms: "The prophecies of what the courts will do in fact, and nothing more pretentious, are what I mean by the law." Oliver W. Holmes, The Path of the Law, in CoLlected Legal Papers 167, 173 (1920). 